\title{
Azerbaycan Tiyatrosu Üzerine Bir İnceleme: Geçmişten Sovyet Dönemine Kadar
}

\author{
DOI: 10.26466/opus. 748125 \\ *
}

\begin{abstract}
Ümit Akın*
* Dr. Öğr. Üyesi , Bandırma On Yedi Eylül Üni., İnsan ve Top. Bil. Fakültesi, Bandırma/Türkiye E-Posta: uakin@bandirma.edu.tr ORCID: 0000-0003-1669-5399
\end{abstract}

$\ddot{O} z$

Edebiyatın önemli kollarından olan tiyatro, olmuş ya da olabilecek konular etrafinda gelişen, bir seyirci topluluğunun önünde canlandırmaya dayanan etki gücü yüksek bir sanattır. Başlangıcı tam olarak bilinmese de ortaya çıkışı, araştırmacılar tarafından Doğu'da M.Ö XII. yüzyıla, Batı'da M.Ö V.-VI. yüzyıla kadar götürülür. Azerbaycan'da da tiyatronun geçmişi çok eskiye götürülmekle birlikte net tarih belirtilemez. Azerbaycan'da modern tiyatro ise 19. yy'ın ortalarından başlamak suretiyle gelişme gösterir. Bu döneme kadarki boşluk Azerbaycan halk tiyatro oyunlarıla doldurulmuştur. En çok oynanan halk oyunları; Mezheke, Kosa Kosa, Kilim Arası, Şah Salim, Karavelli, Şebeh, Sayaçı, Lağlă̆ı, Dervişlik, Kevser, Cütçü Şumu, Yuğg, Tenbeki Kendirbaz vb.dir. Bu oyunlar bir taraftan Azerbaycan'ın kadim tarihini ileriye taşırken diğer taraftan modern Azerbaycan tiyatrosunun oluşmasına katkıda bulunmuştur. Azerbaycan tiyatrosuyla ilgili olarak ülkemizde az çalışmanın olması bizi bu çalışmayı yapmaya sevk etmiştir. Çalışmamız doküman araştırmasına dayalı olup Azerbaycan halk tiyatrosunun başlangıcl, Azerbaycan modern tiyatrosunun teşekkülü ve yükselmesini -Sovyet Dönemi ilk dönemine kadar-esas almaktadır.

Anahtar Kelimeler: Azerbaycan geleneksel halk tiyatrosu, halk oyunları, modernleşme. 


\title{
A Review On Azerbaijani Theatre: From the Past to the Soviet Period
}

\begin{abstract}
Theatre, one of the major branches of literature, is an art with a high power of influence that develops around issues that may or may not have happened, based on the portrayal in front of an audience. Although its beginning is not fully known, its emergence was discovered by researchers in the East as XIIth century BCE, and in the West V-VIth century A.D. In Azerbaijan, the history of the theater is taken back to the past, but no clear date can be specified. Modern theatre in Azerbaijan started to develop in the middle of the 19th century. The gap up to this period has been filled with Azerbaijani folk theatre plays. The most popular folk dances are Mezheke, Kosa Kosa, Kilim Arasi, Shah Salim, Karavelli, Shebeh, Sayaci, Laglagi, Dervish, Kevser, Cutcu Shumu, Yug, Tenbeki Kendirbaz, etc. On the one hand, these plays carried forward the ancient history of Azerbaijan and on the other hand, contributed to the formation of modern Azerbaijani theatre. The fact that there are few studies in our country related to Azerbaijani theatre has led us to do this work. Our work is based on document research and is based on the beginning of Azerbaijani public theatre, the formation, and the rise of Azerbaijani modern theatre-until the first period of the Soviet period.
\end{abstract}

Keywords: Azerbaijan traditional folk theater, folk dances, modernization. 


\section{Giriş}

Bugün bütün toplumların kültüründe büyük önem arz eden tiyatronun, Antik Yunan uygarlığında bağ bozumu (şarap) Tanrısı Dionysos adına düzenlenen şenliklerle ortaya çıtığı kabul edilir. Tiyatro daha sonra dinden bağımsızlaşır ve sanat haline gelir. Mehmet Fuat, Tiyatro Tarihi kitabında tiyatronun dinden daha eski olduğunu söyleyerek onu en eski sanat dalı olarak gösterir (Fuat, 2003, s.9). Tiyatronun kökeninde "ilkel insanın doğa olayların kendi bedensel hareketleriyle simgesel olarak temsil etme" (Güney, 2011, s.136) yatmaktadır. Milletlerin yaşam tarzları, doğa olaylarl, dinsel törenler tiyatronun ana konusunu oluşturur. Azerbaycan'da da tiyatronun ortaya çıkışı tam olarak bilinmese de kökleri çok eskiye dayanır. Azerbaycan Türklerinin yaşam tarzları, gelenek görenekler, dini merasimler, dügünler, tabiat olayları gibi pek çok unsur, tiyatronun kaynaklarını oluşturmaktadır. Düzenlenen bu toplantılar, Azerbaycan halk tiyatrosunun teşekkülünde önemli rol oynar. Aynı zamanda bu oyunlar geçmişle gelecek arasında bir köprü görevi de görür.

Önceleri -yazı bulunmadan- sözlü edebiyat dönemi olarak adlandırdığımız zamanda tiyatronun yazılı bir metni yoktu ve tiyatro doğaçlamaya dayanmaktaydı. Sözlü tiyatro döneminden sonra adım adım yazılı döneme geçildiğinde, sözün yerini tiyatro metni almaya başlar. Böylece modern tiyatronun olmazsa olmaz unsurlarından biri "metin" ortaya çıkar. Metni oluşturan yazar, "yaratıcı gücünü, sanatkâr duyarlılı̆̆ını, geniş muhayyilesini ve kılı kırk yaran kalemi"ni (Çetişli, 2016, s.72) kullanarak tiyatro sanatının yol almasını sağlar. Bundan sonra da tiyatro sahne, dekor, müzik, ses gibi unsurlarla tamamlanarak bütünlük kazanır ve bugünkü anlamdaki modern bir yapıya kavuşur.

Azerbaycan'da geleneksel halk oyunları, 19. yy'ın ortalarından itibaren yerini modern tiyatro oyunlarına birakır ancak bu halk oyunlarından tamamen bir kopuş demek değildir. Örneğin Azerbaycan'da meydan tiyatrosu olarak bilinen geleneksel halk oyununda, Nevruz merasimlerinde yapılan kutlamayla toprağa saygı sergilenir. Atalar kültünde Mart ayının dört çarşambası kutsal kabul edilir; suyun, ateşin, havanın, toprağın uyanışı nedeniyle meydanda birçok geleneksel oyun (kos kosa gibi) oynanır ve bu durum bugün hala devam etmektedir. Azerbaycan dü- 
ğünlerinde de halk oyunlarından bazıları günümüzde hala sergilenmeye devam etmektedir.

Tiyatro sadece sahnede olup biteni göstermez; hayatın her safhasından örnekler sunar. Güldürür, düşündürür, yol gösterir, öğretir, ağlatır bir farkındalık yaratarak arayışlar içine sevk eder. İzleyenlere bazı ipuçları vererek onları düşünmeye yönlendirir. Yani "tiyatronun eğitimsel yönü" (And, 1973, s.58) toplum hayatında büyük önem arz eder. Azerbaycan' da özellikle modern tiyatro oluşurken Müslüman halk nazarında "kâfirlerin tabiî yaşama şekli" gibi birtakım tepkiler gelse de tiyatro yazarları bunu aşmayı başarmıştır. Yani Azerbaycan'da da modern tiyatro; halkı bilinçlendirme, güldürürken düşündürme, aile hayatı, eğitimöğretim gibi mühim meseleler üzerine eğilmiştir.

Azerbaycan'da modern tiyatro Ahundzade'yle başlatılır. Onun çizgisi Necef Bey Vezirov'la devam eder. Daha sonra Reşit Bey Efendiyev, Sakine Hanım Ahundzade, Celil Mehmet Kuluzade, Neriman Nerimanov, Abdurrahim Bey Hakverdiyev, Abdulla Şaik, Hüseyin Cavid, Üzeyir Hacıbeyli, Cafer Cabbarlı'yla Azerbaycan modern tiyatrosu ilerleme kaydeder. Bu tiyatro yazarları eserlerinde bir yandan Azerbaycan hayatını realist ve eleştirel bakış açısıyla ortaya koyarken diğer yandan sorunlara çözüm önerileri sunmaya da çalışır.

Çalışmamızda önce Azerbaycan tiyatrosunun doğuşu ele alınacak, daha sonra Azerbaycan modern tiyatrosunun gelişmesi ve yükselmesi yukarıda belirtilen isimler dâhilinde açıklanacaktır. Açıklamalar yapılırken Azerbaycan'ın siyasî, içtimaî manzarasına da değinilecektir.

\section{Azerbaycan'da Tiyatronun Doğuşu}

Azerbaycan tiyatrosunun başlangıcı konusunda araştırmacılar, belli bir tarih işaret etmemekle birlikte onu çok eskilere gittiğini belirtir. ${ }^{1}$ Azerbaycan'da modern tiyatroya geçilmeden önce halk arasında oynanan geleneksel oyunlar vard1. Bunlara halk tiyatrosu ya da meydanlarda oynandığ 1 için meydan tiyatrosu denirdi. Meydanlarda oynanan oyunların Azerbaycan halkı için çok önemli olduğunu dile getiren İlham Rəhimli, Azərbaycan Teatr Tarixi kitabında bu konuyla ilgili şunları yazmiştır:

\footnotetext{
${ }^{1}$ Bkz. Cafer Cabbarlı (1959). Azerbaycan Dram Teatrı, Bakü: Azerbaycan Dövlet Neşriyatı, s. 35; Rahimli, i. (2005). Azerbaycan Teatr Tarixi. Bakü: Çaşıoğlu, ss. 3-5.
} 
"Meydan tiyatroları, halkın manevi varlı̆̆ın, hayatın birtakım sorunlarını, dünyanın bitmek tükenmek bilmez hadiselerini, mitoloji ve folklorik unsurlarm,, değişik şekillerde işleyen ve farklı üslupta ele alan zengin bir kaynaktır." (Rahimli, 2005, s.6)

Azerbaycan halk oyunları, modern tiyatronun oluşmasında önemli rol oynamıştır. Azerbaycan hayatında bu tiyatrolar, her zaman ilgi görmüş geleneksel tiyatro anlamında zengin bir oyun yelpazesi kazandırmıştır. En çok oynanan halk oyunları; Mezheke, Kos Kosa, Kilim Arası, Karavelli, Şebeh, Sayaçı, Lağlağı, Dervişlik, Kevser, Cütçü Şumu, Yuğ, Tenbeki Kendirbaz, Yel Baba-Dede, Godu-Godu, Güdül'dür (Cabbarlı, 1959, s.4).

Mezheke/Müdhike; halk oyunlarının en önemlilerinden biridir. Bu oyunda zıt karakterli insanlar, cahillik, maneviyatsızlık, ahlaksızlık gibi cemiyetin kusurlu taraflarıyla gösterilmeye çalışılır.

Kos kosa oyunu; Nevruz Bayramlarında oynanır. Birçok çeşidi olmakla birlikte en çok oynanan Köse ve Keçel karakterlerindeki oyuncuların oyunudur. Bu oyunda keçi, kurt çakal, boğa gibi maskeler vardır. Oyunun içine bilmecelerle halk da dâhil edilir. Köse ilkbaharı, Keçel ise kışı simgeler. Aralarındaki diyaloglar ve maniler komik olsa da mesajlar içerir. Bu oyun Anadolu'da da oynanmaktadır. Genellikle Şubat'ın çille denilen bir gününde oynanır. Geçici bir kral, şah, vali seçilir. Bu kişinin her emri yerine getirilir. Eski yılı simgeleyen kralın süresi bitince kral aşağılanır ve kovulur. Bu durum eski yılın kovularak yeni yılın sevinçle karşılanması demektir (And, 2010, s.21).

Kilim Arası oyunu; Azerbaycan'ın kukla oyunu olarak bilinmektedir. Oyunun geçmişi çok eskiye gitmektedir. Birçok çeşidi olan bu oyunun en çok tercih edileni "bebek" oyunudur. Bunun için bebek isimli kuklalardan yararlanılır. Gösteriyi yapan kişi Keçekpelvan'dır. Bazen küçük bazen de 4-5 yaşındaki bir çocuk boyunda olan kuklalar, kilimin üstünde değişik hareketlerle Keçelpelvan tarafından sergilenir. Kuklalarla halka mesajlar verilir (Rəhimli, s.19).

Karavelli; Komedi şeklinde olan bu oyunlara daha çok orta asırlarda nişan, düğün törenlerinde yer verilmiştir. Masal ve fikra arasında bir tür olarak değerlendirilebilir. Toplumu eğlendirme amacı güden bu oyunda Karavelli anlatılarak tören eğlenceli hale gelir. Ülkemizde Doğu Anadolu Bölgesi'nde de karavelli anlatımı görülmektedir. Karavelli konusunda 
araştırma yapan Tahir Oruçov, bu oyunların köy seyirlik oyunlarında da sergilendiğini söyler (Oruçov, 2006, s.142-143).

Azerbaycan halk oyunları arasında en yaygın olanlardan birisi de "Şebeh" oyunudur. Oyunun içeriğini Kerbala Olayı oluşturmaktadır. Kerbala'da katledilerek şehit edilen Hz. Hüseyin ve onun taraftarları konuda işlenir. Azerbaycan'da Şebeh oyunlarının sıklıkla oynanması Şiîliği halka benimseterek onu yaymak amacı taşımaktadır. Bu oyunların birçoğu kimin tarafından yazıldığı bilinmese de İslam tarihi içinde yaşanan olaylar ele alınmıştır. "Ali'nin Katli", "Hazreti Abbas'ın Şehit Olması", "Müslüm'ün Oğlanlarının Katli”, "Kerbela Musibeti”, "Kasım Otağ1", İmam Hüseynin Katli", "Müslüm'ün Kufe'de Katli" gibi oyunlar Şebeh oyununda yer almaktadır (Caferov, 1959, s.4).

Sayaçı; Azerbaycan'ın en meşhur halk oyunlarından biridir. Göçebe Türklerin koyun otlatma işiyle meşgul olanları, koyunların yünlerinin kırkılması ve kuzulama zamanlarında gerçekleşen bir merasimdir. Oyuncular bu durumu bayatılar söyleyerek, maniler bağırarak anlatırlar. Bolluk ve bereketi simgeleyen bu oyun ülkemizde Yozgat yöresinde de oynanmaktadır. Sayaçılar kapı kapı gezip sayaçı nağmeleri okuyarak karşılığında peynir, un, yă̆, buğday, pirinç alırlar.

Lağlağı; oyunu güldürme ve eğlendirme özelliğiyle ön plana çıkmıştır. Sanatını ortaya çıkarmak isteyen bir kişinin şehir içinde giyim kuşa$\mathrm{m}$ son derece iyi olan birini bularak onunla uğraşması şeklinde oynanır (Rəhimli, 2005, s.7).

Dervişlik; birtakım sihir oyunları yaparak halkın eğlendirmeyi amaçlayan oyundur. Dervişler deriden yapılmış ya da kalın kumaşlardan yapılan paltolar giyerek ortaya çıkar. Azerbaycan tiyatrosu araştırmacılarından olan İlham Rehimli, bu oyunun tarihini XI. yy'a kadar götürmektedir. Ona göre dervişler önceden tarikatların temsilcisi gibi gittikleri yerlerde dini kuralları anlatmışlardır. Ancak sonradan gözleri bağlı zehirli yılanları ve akrepleri oynatarak ritmik hareketli oyunlar oynamışlardır. Onların bu temaşası "derviş merekesi" olarak da adlandırılır (Rəhimli, s.7).

Kevser oyun; kışın zorlu şartlarına göğüs germek, buna önlem almak, kışı korkutarak onun daha hafif gelmesini sağlamak amacıyla oynanan bir oyundur. Bu nedenle bu oyunu oynayan kişinin güçlü, akıllı ve bece- 
rikli olması gerekir. Bu kişi gözleri bağlanıp, ata bindirilerek civar yerleri gezmesi ve böylece kışı korkutması amaçlanır.

Cütcü Şumu oyunu; toprağa tapan insanları gözler önüne serer. Nevruz bayramının toprak çarşambasında oynanan bu oyun, az ekilerek çok verimin alındığı yerde oynanır. Bu oyunun bir kuralıdır.

Yuğ; İslamiyet öncesi Türk edebiyatında da olan bu merasimde kahramanlar ağlayarak anılır. Bunun için herkes bir yerde toplanır, ağlama konusunda ün yapmış kişiler özel davet edilirdi. Ölen kahraman kişinin ardından ağıt yakılır, onun cesaretli tavrı ele alınır.

Tenbeki oyunu; genellikle şehirlerde oynanan bir oyundur. Bir oyun meydanı bulunur ve orada geçmişte yaşanan gerçek bir hadise ele alınır. Oyuncular bu hadiseyi anlatırken aynı zamanda topluma ders de verir.

Kendirbaz oyununda; iki ağacın çatallaşan kısımlarına ip bağlanır. Oyuncu bu ipin üstüne çıkarak çeşitli hareketler sergiler. Yardımcısı keçepapaq ise aşağıda kendirbazın yaptığı hareketlerin aynısını yapmaya çalışır. Kendirbaz oyunları şehir meydanlarında, pazarlarda, kervansaraylarda, piknik yerlerinde gösterilirdi (Rəhimli, s.8). Hareketler yapıldıktan sonra izleyenlerden para toplamak için maniler söyler. Bizdeki ip cambazı oyunudur.

Yel Baba-Yel Dede oyunu; tarlalardan ekinin biçilip harmanlara koyulmasının ardından başlar. Oyun bu konu üzerine kurulduğu için ekilip biçilme zamanı beklenir. O seneki verimin iyi olması adına harmanlarda Yel Dede" yardıma çağrılır. Çağrılma esnasında birtakım nağmeler okunur. Hasat zamanı Yel Dede'nin gelmesiyle mahsul temizlenir ve bu duruma halk çeşitli ezgilerle eşlik eder. Azerbaycan halkın inancına göre yeryüzündeki bütün rüzgârların yetkisi mitolojik varlık Yel Dede'dir ve bu oyunda Şamanizm'in izleri görülür. Yel Dede'yi çağırmak için söylenen şarkılar rüzgârla sohbet etmek, ondan yardım istemek, çok şiddetli estiğinde onun sinirlendiğini düşünmek, bir annenin ilk çocuğunun şarkı söyleyerek oyuna katılması, Şamanistlerin doğa güçlerine karşı yaptığ1 merasimlere ve ayinlere benzer (Mehmedova, 2017, s.140).

Godu-Godu oyunu; Azerbaycan halk oyunlarının en önemlilerinden biridir. Bu oyunda uzun süre yağan yağmurların ekinlere zarar vermemesi için kapı kapı gezilerek nağmeler okunur. Güneş çağrılır. Nağmeler, kukla şeklinde yapılan ve adı Godu olan kişinin şanı için yapılır. Godu, aslında güneşi temsil eden bir simgedir. Anadolu'da da bu oyun 
vardır. Rize, Trabzon yörelerinde yağmurların uzun sürmesi mahsule zarar vereceğinden güneş duası yapılarak güneş çağrılır (Çelebi, 2007, s.111).

Güdül; Godu-Godu'nun zıttı bir oyundur. Bu oyunda da uzun süren kuraklıklar sonucunda yağmur çağrılır. Güdül yağmuru temsil eden bir simgedir. Tarlalar yaşanan kuraklıktan dolayı kurumuş, bu yüzden yağmur isteyen nağmeler okunur.

Azerbaycan'da pandomim esaslı oyunlar "lal oyunu" farklı çeşitleriyle sergilenirdi. Bu oyunların da özellikleriyle kısaca verilmesinin faydalı olacağını düşünmekteyiz.

Bu oyunların arasında en çok oynananı "Bağ belleme" oyunudur. Bazen tek bazen de bir-iki kişiyle oynanır. Oyuncu, yaz mevsiminin gelmeye başladığını ve bağ belleme zamanının geldiğini jest ve mimikleriyle anlatmaya çalışır. Oyunda mânânın ve düşünsel gülüşün olması bu oyunu önemli kılar.

"Kaftarkus" oyununda oyuncular, ölünün dirilmesini değişik hareketlerle gülünç bir şekilde anlatmaya çalışırlar. Bu oyunda birden fazla oyuncu bulunur.

"Kar Toyu" oyununda oyuncunun hareketlerini müzik takip eder.

Heykel, abide anlamına gelen "mücesseme" oyununda; ağa ve hizmetçi, köylü ve zengin gibi zıt karakterler üzerinden konu anlatılır. Oyun sade olmakla birlikte içerisinde birçok mânâ taşır.

Kör Döğüşü oyununda; görmediği varsayılan iki kişinin birbiriyle olan komik hareketleri, kavgaları, tartışmaları gözler önüne serilir.

Lal oyunlarının (pandomim) hayvanları anlatan "Lökleme", "Maral oyunu" adlı kısa oyunları da vardır. Maral oyununda iki kişi hayvan kıyafetleri giyerek ya da özel dikilmiş ceylan postunu giyerek ceylanın otlaması, vahşi hayvanlardan nasıl kaçtı̆̆ı anlatılır. "Lökleme”de ise yük altında olan devenin (lök, ner, maya...) hareket tarzı oyuncunun jestleriyle anlatılır. Bu oyuna Devetabanı ismi de verilmektedir (Rəhimli, 8).

Yukarıda belirtilen halk oyunları, Azerbaycan'da geleneksel tiyatronun gelişmesine katkıda bulunduğu kadar karakterlerin ve tiplerin zenginleşmesini de sağlamıştır. Açıklamaya çalıştığımız Azerbaycan geleneksel halk tiyatrosu, görüldüğü üzere zengin bir nitelik taşımaktadır. Birçok konuda oynanan bu oyunların halkı eğlendirmenin yanı sıra halka mesajlar vermesi de bu oyunları önemli kılmıştır. Ayrıca halk oyunla- 
rının ve oyuncuların Azerbaycan profesyonel tiyatrosunun oluşumuna katkı sağlaması da halk tiyatrolarının değerini daha da arttırmıştır. Sıdkı Ruhulla, Abbas Mirza Şerifzade, Hüseyin Araplinski gibi oyuncular, yazılı tiyatrodan önce halk tiyatrosunda oynamışlar, daha sonra Azerbaycan tiyatrosunun sahnesine çıkan ilk oyuncular olmuşlardır.

\section{Modern Azerbaycan Tiyatrosunun Teşekkülü}

Azerbaycan Dram Edebiyatı adlı eserinde Vahap Yurtsever, Azerbaycan'da modern tiyatronun XIX. yüzyılın ikinci yarısında ortaya çıktığını, bunun böyle olmasını da Rusya-İran Savaşı sonucunda Kuzey Azerbaycan'ın Rusya'ya ilhak edilmesinin etkili olduğunu belirtir (Yurtsever, 1950, s.6). Bu durumu işgalden sonra Azerbaycan'ın siyasî, ekonomik ve kültürel bakımdan Rusya'ya bağlı olmasına dayandırabiliriz.

Osmanlı' da ilk tiyatro etkinlikleri nasıl gayrimüslimlerin yoğun yaşadığı yerlerde ortaya çıkmışsa Azerbaycan'da da ilk tiyatro faaliyetleri Rusların etkisiyle ortaya çıkmıştır. Tiflis'te ilk tiyatro binasının temelinin atılması (1849) ve açılışının dönemin umumî valisi Knyaz Vorontsov tarafından 1851'de yapılması bunu doğrular niteliktedir. Vorontsov, Kafkasya' da Ruslara bağlı milletlerin Türk, Gürcü, Ermenilerin aydınlarını, tiyatro eserleri yazmak için teşvik çalışmalarında da bulunmuştur (Akpınar, 1994, s.58). Bu teşvikler neticesinde Müslüman dünyasının modern anlamdaki ilk tiyatro yazarı Mirza Fethali Ahundov (1812-1878) ortaya çımış, 1850 'de Hekayet-i Molla İbrahimhalil Kimyager eserini yazmiştır.

Halk yaşamını iyi bilen ve bunu komedilerinde gösteren Ahundov, sanatın halk için yapılması gerektiğini düşünüyor ve bunu gerek tiyatrolarında gerekse makalelerinde dile getirmeye çalışıyordur. Okumayazmanın az olduğu toplumlarda problemlere tiyatrolarıyla çözüm bulmaya çalışmış, toplumsal meseleleri bu şekilde halletmek yoluna gitmiştir. Azerbaycan'da yeni edebiyatın kurucularından sayılan, modern tiyatronun kurulmasında ve gelişmesinde büyük rol oynayan, inkılapçı, halkçı Ahundov 1878'de kalp rahatsızlığından vefat etmiş ve vasiyeti gereği hocası Mirza Şefi Vazeh'in yanına gömülmüştür.

Ahundov, ilk eserini yazdığı yılda Hekayet-i Mösyö Jordan Hekimi- Nebatat ve Derviş Mesteli Şah Cadukini-Meşhur (Mösyö Jordan) ve Lenkeran 
Hanııın Veziri eserlerini de yazmıştır. Azerbaycan'ın yenilikçi modern aydını Ahundov, 1852'de Hekayet-i Hors-ı Guldurbasan'ı, 1853'te Hacı Gara'yı, 1855'te Mürafaa Vekilleri'ni yazmıştır. Ancak yazılan bu eserler, 1859'a kadar anadilinde yani Azerbaycan Türkçesinde Rus sansürü nedeniyle bastırılamamıştır. Bu konuda Yavuz Akpınar şunları söyler:

"Ahundov, herhalde sansür meselesini göz önünde tuttuğu için olacak, kendisi bir yandan komedileri yazarken bir yandan da Rusçaya çevirmiştir. 1851'den itibaren bu Rusça çevirileri, Türkçelerinden daha önce bastırır. Tercümeler Kavkaz adlı Tiflis'te yayınlanan Rusça gazetede art arda neşredilir. Kaderin bir cilvesi olarak Azerî Türkçesiyle kaleme alınmış olan bu ilk tiyatro eserleri Rusça olarak bastırildıklarn gibi sahneye de daha önce Rusça ve Ruslar tarafindan konulur. Komediler yine Rusça olarak 1853'te Tiflis'te kitap halinde neşredilirler. Türkçe orijinalleri ancak 1859'dan sonra kitap halinde Temsilat adıyla bastırllır. Bu baskıya Ahundov'un komedilerinden sonra kaleme aldığ Aldanmış Kevakib veya Yusuf Şah adıyla bilinen modern bir hikâye ilave edilmiştir." (Akpınar, 1994, s.59)

Ahundov'un eserlerinin ilk kez Rusça sahnelenmesi pek de şaşırtıcı değildir. Nedeni Müslüman dünyasının o dönemde modern anlamdaki tiyatro hakkında bilgi sahibi olmaması gelmektedir. Bu yüzden Ahundov'un ilk eserleri Ruslar ve gayrimüslimler tarafından oynanmıştır.

Ahundov'un yazdığı komediler -Rusça dışında- Almancaya, Farsçaya, İngilizceye ve Fransızcaya da çevrilmiş hem İslam dünyasında hem de Batıda büyük şöhret kazanmıştır. Eserleri sade bir dille ele alınmış, içerdiği konular bakımından da toplumdaki aksaklıklar ortaya konmaya çalışılmıştır. Ahundov'un eserlerinin önemli bir yanını Rus işgalinden sonra Azerbaycan Türk toplumunda yaşanan değişimin oldukça gerçekçi bir şekilde anlatmış olması gelmektedir. Tiyatrolar bir taraftan dönemin birçok önemli hadisesini anlatırken bir taraftan da toplumda başlayan değişimi bütün karakteristik özellikleriyle ortaya koymaktadır.

Ahundov'un sahnelenen ilk tiyatro eseri Mösyö Jordan (1851)'dır. Sahnelenen ikinci tiyatro eseri Hekayet-i Hirs-ı Guldurbasan (1852)'dır. Hekayet-i Molla İbrahimhalil Kimyager ve Mösyö Jordan komedilerinde Ahundov, yalnız eserde geçen Molla İbrahim ve Derviş Mesteli Şah gibi yalan$\mathrm{Cl}$, ahlaksız ve dolandırıcı kimyacı ve dervişi değil dönemin baskıcı ve derebeylik yönetimi karşısındaki toplumların hayatını eleştirir. Hekayet-i Hırs- $\iota$ Guldurbasan komedisinde kadın erkek ilişkilerini ele alır ve eleştiri- 
sini bu yönde değerlendirir. Konusunu 1800'lü yıllardaki hanlıklar devrinden alan Lenkeran Hanının Veziri adlı eserinde Ahundov, birçok önemli hususu birlikte ele alır. İki evlilik, han yönetiminin adaletsizliği, aile, feodal düzen gibi konulardaki görüşleri açılamaya çalışır. Ahundov'un hayat gözlemlerinin ve güçlü sanatkârlık kudretinin ürünü olan $\mathrm{Hacl}$ Gara komedisi Azerbaycan'ın en önemli tiyatro eserleri arasında sayılmaktadır. Bu eserde yazar Azerbaycan'ın Rusya'ya bağlanmasından sonraki değişimi gözler önüne sermektedir. Ahundov'un son tiyatrosu olan Mürafaa Vekilleri'nde yazar, toplumda yaşanan düzensizliklere, dalaverelere, kültürel bozukluğa ve eşitsizliğe dikkat çekmek ister.

Mirza Fethali Ahundov, eserlerini kendi toplumu için yazmışsa da sansür nedeniyle anadilinde ancak 1873 'te oynanmaya başlar. Azərbaycan Dram Teatrı eserinde Cafer Cabbarlı Azerbaycan'da oynanan ilk tiyatro eserinin oynanması ve tarihiyle ilgili bir ikilemin olduğundan bahsederek şu bilgileri verir:

"Azerbaycan Ilimler Akademisi maruzalarında XI. No,6 "Azarbaycan Teatrn Tarihina Dair" adlı makale arşiv materyallerin esasina verilen malumata göre 1857-1858 yıllarında Şamahi'da 'Mukaddes Nina' mektebi yararna tiyatro temaşalar gösterilmiştir. Bu temaşalar o kadar muvaffakiyetli geçmiştir ki Şamahı'da yeni bir tiyatro binası dikme fikri meydana çıkmıştır. Ağabey Zeynalbeyoğlu adlı birisinin ayırdığı 1500 Manat pulla Şamahı'da olan köhne 'Duz Mağazası' Azerbaycanlı mimar Kasımbey Hacıbababeyoğlu'nun layihası esasına parteri, localar olan bir tiyatro binasına çevrilmiştir. Lakin gösterilen temaşaların neden ibaret olduğu ve hangi dilde oynandiğı malum olmadığından Azerbaycan tiyatrosunun tarihinin 1857-1858'li yıllardan başladığını tasdik etmek için yeterli diyemeyiz. Diğer mesele ondan ibarettir ki 1873. yılda Realni mektep şakirtleri tarafindan gösterilen ilk temaşa hakkında iki muhtelif malumat vardır. Illk temaşa için icaze alınması ile alakadar olan birçok resmi senetler ve M.F. Ahundov'un arşivinden tapılan afişadan malum olur ki Martın 10'da Nevruz Bayram gününde "Lenkeran Hanının Veziri" oynanmıştır. Lakin Zerdabi'nin 'Müselman Tiyatrosunun Binasi' adl makalesinde (Hayat, 1905, 13 Dekabr) ve N.B. Vezirov'un tercüme-i halinde ise ilk temaşanın "Hacı Gara" olduğu kaydedilir." (Cabbarll, 1959, s.35-36)

Bugün Azerbaycan'da da Azerbaycan Türkçesiyle sahnelenen ilk oyun "Hacı Gara" olarak kabul edilir. Konuyla ilgili Cafer Cabbarlı'nın yukarıda verdiği bilgilerden ve sunduğu afişten anlaşılmaktadır ki 10 
Mart 1873 'te ilk oynanan tiyatro eseri "Lenkeran Hanının Veziri" kabul edilmelidir.

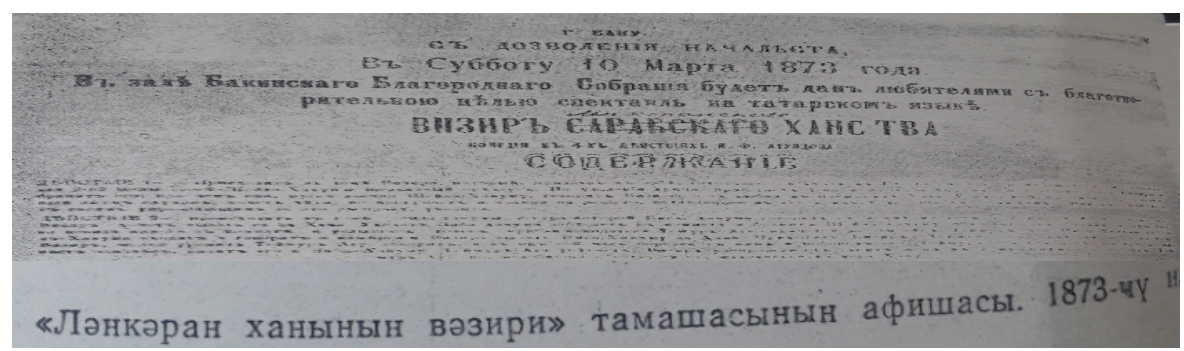

Fotoğraf: Cafer Cabbarlı, 1959: s.39.

Azerbaycan Türkçesiyle oynanan diğer oyun ise Haziran 1873'te "Sergüzeşt-i Merd-i Hasis" yani "Hacı Gara"dır. ${ }^{2}$ Bu oyun Rus okulu olan Realni Mektebi'nin içlerinde geleceğin modern tiyatro yazarı olacak olan Necef Bey Vezirov'un da bulunduğu son sınıf öğrencileri tarafından oynanmıştır. Oyun Azerbaycan'ın ilk Türkçe gazetesini neşreden Hasan Bey Zerdabi'nin rehberliğinde oynanmıştır. Zerdabi, Necef Bey'in hocasıdır. Bu oyun tekrar tekrar oynanmış, halktan büyük rağbet görmüştür. Ama Müslümanların bazıları da Zerdabi'yi lanetleyerek ona tehdit mektupları göndermiştir. Bunlara cevap olarak Zerdabi, "Bunlar bizim onlara dost olduğumuzu anlayacaklar. Mektebin, tiyatronun menfaatini anlamıyorlar. Onlar için gazete de verebilsem onların şuurunu tamamıyla değiştirebilirim (Cabbarlı, s.41) demiş, mücadeleden vazgeçmeyeceğini belirtmiştir. Bu tiyatro oyunundan sonra tiyatroda profesyonelleşme çalışmaları yavaş yavaş başlamış ve tiyatro faaliyetlerinde bir hareketlilik gözlenmiştir. Tiyatroda bu yıllarda görünen değişimi Azerbaycan edebiyatı araştırmacısı Akpınar şöyle açıklamaktadır:

"1880 yılindan sonra tiyatro faaliyetlerinde bir canlanma görülür. Gori Muallim mektebini bitiren gençler, gittikleri yerlerde öğrencilerini başlarına

\footnotetext{
${ }^{2}$ Azerbaycan tiyatro araştırmacılarından Ağakerim Şerifov da "Azerbaycan Türk Tiyatro Tarihi Materyalleri" kitabında oynanan ilk oyunu Lenkeran Hanı'nın Veziri olarak gösterir. Yine Ismail Cahangirov'un 1932'de yayımladığı "Azerbaycan Dövlet Bedaye Tiyatrosu" adlı kitap da ilk oyun olarak Lenkeran Hanı'nın Veziri gösterir. 1949'da Azerbaycan tiyatrosunun 75. Yıllı̆̆ıla ilgili ilgili düzenlenen arşiv materyallerinde aynı eser kabul edilir. 1950'de Azerbaycan Ilimler Akademisince yayımlanan "Azerbaycan incesanat" mecmuasının tiyatro tarihine hasr edilmiş üçüncü cildinde de "Lenkeran Hanı́nın Veziri" esas gösterilir (Bkz. Cabbarlı, 1959, s.37).
} 
toplayarak çeşitli eserleri sahneleştiriyorlardı. 1880 yılında ilk profesyonel denilebilecek "dram cemiyeti" Nahçivan'da teşkil edildi. Bu tiyatro cemiyetinin en önemli üyeleri yine muallimlerdi. Memmedtağı Sıdkı, Celil Mehmetguluoğlu, Ekber Molla Beyelioğlu, Eyneli Sultanof vs. gibi 1882 yılından itibaren Azerî Türkçesini bilen Ermeni aktör ve aktristleri; Almaz Hanım, Stepan Safrazyanlar Azerbaycan'ın birçok şehirlerinde temsiller vermeye başladı. Bunlar başta Ahundov'un olmak üzere "Gırt-girt" adlı vodvilin yazarı Vasak Medetyan'ın Azerî Türkçesiyle yazmış olduğu bazı basit piyesleri oynuyorlardı. Yine 1880'de Bakü'de nuallim Habib Bey Mahmutbeyof, Sultan Mecid Ganizade, Necefgulu Veliyev bir tiyatro topluluğu oluşturdular." (Akpinar, 1994, s.59-60)

Tiyatronun büyük terbiyevi ehemmiyetini anlayan Azerbaycanlı bazı aydınlar, sadece Bakü'de değil Guba, Nuha, Şuşa, Nahçivan'da tiyatro gösterileri yapmışlardır. 1882'den itibaren Azerbaycan Türkçesini mükemmel bilen profesyonel Ermeni aktörleri Elmas Hanım ve Stepan Safrazyonal birçok şehirde Bakü, Gence, Şuşa, Nuha'da tiyatrolar sergiler. Bu dönemde özellikle Ahundov'un eserleri ve Vasaq Medetov'un Azerbaycan Türkçesinde yazdığı "Gırt-Gırt" eseri oynanır (Cabbarlı, 1959, s.43).

Çeşitli edebî ve kültürel faaliyetleriyle sosyal mazmunu ve düşünce istikâmeti açısından Türk dünyasının önemli eğitimci yazar ve mütefekkirlerinden olan Mirza Fethali Ahundov, eserlerinde feodal idare yönetimine, zulüm ve yolsuzluğa, adaletsizlik ve kanunsuzluğa cehalet, dini fanatizm ve tembelliğe karşı çıkmıştır. Halkının ve genel olarak Doğu halklarının millî intibahı, ekonomik ve kültürel terakkisi, çalışkan kitlelerin hür ve mutlu hayatı için aktif bir şekilde mücadele etmiştir (Məmmədov, 2005, s.4).

\section{Modern Azerbaycan Tiyatrosu'nun Yükseliş Devri}

1880'li yılların sonuna doğru muayyen bir tiyatro kolektifi (Habib Bey Mahmutbeyov, Sultan Mecit Ganizade, Necefgulu Veliyev) oluştu. Bu kolektifte buluşan tiyatro sevdalıları, milletin terakkisi için en önemli faaliyet sahasını tiyatro olarak hesap ederler. Zaman zaman, yobazların, cahillerin hücumlarına uğrasalar da Azerbaycan tiyatrosunun gelişmesi için yorulmadan çalışmışlar, mensubu olduğu milleti ileriye taşımaya gayret göstermişlerdir. Azerbaycan tiyatrosunun bu yıllarda gelişmesin- 
de büyük katkılar sunan Hasan Bey Zerdabi, Necef Bey Vezirov, Sultan Mecit Ganizade ve Neriman Nerimanov, bazen aktör, bazen rejisör, bazen de piyes yazarı olarak birkaç işi birden yapmışlardır. Azerbaycan'ın petrol zengini Hacı Zeynel Abidin'in 1883'te Bakü'de hususî bir tiyatro binası yaptırması, Azerbaycan modern tiyatrosunun gelişmesinde uygun ortamı sağlamıştır.

Azerbaycan'da ilk tiyatro oyunları genellikle bayram günlerinde oynanır, tiyatronun giriş kısmında ehemmiyeti ve gösterilecek oyunla ilgili kısa bir giriş nutku söylenirdi. İlk zamanlar tiyatro repertuvarında Ahundov'un komedileri yer alırdı. Daha sonra N. B. Vezirov, Vasaq Medetov gibi diğer tiyatro yazarlarının eserleri oynanırdı. 1890'lı yıllarda yaratıcılığa başlayan Neriman Nerimanov, Haşım Bey Vezirov, Reşit Bey Efendiyev, Celil Mehmetkuluzade gibi yazarlar, Ahundov'un yolundan giderek Azerbaycan hayatını realist bir şekilde tasvir etmişler, sorunları göstermekle kalmamış, çözüm önerilerini de vermeye çalışmışlardır.

Azerbaycan modern tiyatronun kurucusu sayılan Mirza Fethali Ahundov'dan sonra onun çizgisini daha da ileri taşımaya gayret gösteren ikinci isim Necef Bey Vezirov (1854-1926)'dur. Çok sayıda tiyatro eseri olan Necef Bey, edebî faaliyetlerine tiyatroyla başlamış, Ahundov'un Hacı Gara komedisindeki kadın rolüyle Azerbaycan modern tiyatrosunun ilk Müslüman oyuncularından olmuştur. $\mathrm{O}$, tiyatro eserlerini realist bir bakış açısıyla yazmış, sanatı toplum için yapılan bir değer olarak görmüştür. Eserlerinde Azerbaycan hayatının içtimaî, siyasî ekonomik ve ahlakî sorunlarını ele almış geniş perspektifte Rusya Müslümanlarının Avrupa medeniyetlerinden geri kalış sebeplerini gerekçeleriyle açıklamıştır. Necef Bey Vezirov'un 1896'da yazdığ Musibet-i Fahreddin, adlı tiyatro eseri, Azerbaycan'ın tiytrosunun ilk trajedisidir (Akın, 2018: 62).

Öğrencilik yıllarından itibaren sanat faaliyetleri içerisinde yer alan Necef Bey Vezirov'un tiyatro eserleri, hikâyeleri, çeşitli gazetelerde yayımladığı edebî fikir yazıları, uyarlamaları, tercümesi, şiirleri ve Azerbaycan tabiat bilimleriyle ilgili yazıları vardır. Edebiyatın birçok çeşidinde eser vermişse de Azerbaycan'da daha çok tiyatro yazarı olarak bilinmektedir. O sanatsal gücünü tiyatrolarıyla kazanmıştır. Necef Bey Vezirov'un kaynaklarda yirmi civarında tiyatro eseri belirtilmektedir. Fakat bu tiyatroların bir kısmı günümüze ulaşamadan kaybolmuştur. Onun 
tiyatroları Azerbaycan hayatını aksettiren bir ayna vazifesi görür. Müslüman dünyasının diğer medeniyetlerden geri kalmasının sebebini cahillik olarak verir. Eserlerindeki içtimaî sorunların hemen hepsini buna bağlar. Halkçı özellikler ve halk ruhu, Vezirov'un tiyatrolarında folklorik unsurlar olarak da kendini gösterir. Kimi zaman halk deyişleriyle, kimi zaman halk şiirleriyle kimi zaman da ananevî unsurlarla bu durum ortaya çıkar.

Vezirov tiyatro eserlerinde üzerinde durduğu önemli konulardan biri de toprak ağalarının hayatıdır. Maddi iflasa uğrayan bu ağaların hâlâ eski kurallarla yaşamaya çalışmasını gülünç şekilde ortaya koyar. Yazar, bundan kurtulmanın yolunu ise hangi tabakadan olursa olsun eğitim yoluyla olacağını her fırsatta dile getirir. XIX. yüzyılın son çeyreği itibariyle petrol şehri Bakü, sanayi ve ticaret merkezi olmuştur. Değişen hayat tarzları ve kişi tipi, Vezirov'un tiyatrolarında tacir-burjuva suretleriyle karşımıza çıkar. İkiyüzlü, çıkarcı, açgözlü, para düşkünü, yalancı, ahlaksız tacir-burjuva sınıfı yazar tarafından cezalandırılır ve keskin bir şekilde tenkit edilir.

Vezirov'un "Eti Senin Sümüyü (Kemiği) Benim" eseri şahsi arşivinde bulunmasa da eserle ilgili bilgi Sefa Maarif Cemiyeti tarafından "eğitimle ilgili" olduğu çok kısa olarak belirtilir (Sefa, 1913, s.17). Eserin ismi aslında bize bir şeyler çağrıştırmaktadır. Ailelerimiz çocuklarını eğitim ya da usta-çırak ilişkileri konusunda eğitim verecek kurumlardaki kişilere teslim ederken genelde "Eti Senin Kemiği Benim" der ve onu iyi eğitmesi konusunda muallimlere telkinde bulunur. İşte Necef Bey Vezirov da eserlerini yazarken tanık olduğu olayları eserinin konusu yapmıştır. $\mathrm{Bu}$ eser çok büyük bir ihtimalle Azerbaycan aile hayatında çocukların eğitim konusunu ele almaktadır. Bu yorumu bize Necef Bey'in gazete yazılarındaki eğitim yazıları yaptırmaktadır. Mesela Ekinçi gazetesine gönderdiği bir yazısında bu eserin ismiyle ilgili bir kısım da vardır ve eğitim konusunda ailelere tenkit yöneltmektedir: "Bizim muallim, uşak için celladdır. Uşă̆ı dövmeye papiros çekmeye adet eden teki adet edibdir. Deyir: Uşak dövülmezse okumaz. Güya ol biçare eşektir ki bizlemesen yerimez. Ata ve ana uşağı ona tapşıranda der: Eti Senin, Sümüyü Benim, döv ki adam olsun...(Necef, 2005, s.409)" Eserin eğitim konusunda yazıldığı bilgisi, Vezirov'un kırk yıllık jübilesi münasebetiyle Sefa Maarif Cemiyeti tarafından hazırlanan yirmi iki sayfalık kitapta da verilmiştir. Eserin tamamı eli- 
mizde mevcut değildir. Sefa Maarif Cemiyetince Arap harfleriyle Azerbaycan Türkçesinde yazılan "Necef Bey Vezirov" ${ }^{3}$ kitabının on yedinci sayfasında onun ilk ve kaybolmuş eseri "Eti Senin Sümüyü Benim" hakkında şu bilgi verilmektedir:

"Bu müdhike (komedi) üç perdeli olup millî yaşayışımızdan mektep baresinde yazılmıştır. Birinci eseridir ki 1873 Eylül'de yazılmıştır." (SEFA, 1913, s17)

Necef Bey Vezirov, "Ev Terbiyesinin Bir Şekli" tiyatro eserini 1875'te Erivan'da yazmıştır. Eser, kaba ve medeniyetsiz baba Bayramali Bey ile tembel ve terbiyesiz oğullar Safterkulu ve Resul arasındaki münakaşalar üzerine kurulmuştur. Vezirov, "Ev Terbiyesinin Bir Şekli" nde tasvir ettiği kusurlu aile davranış tarzlarının sebebini yüz yıllar boyu süregelen ve nesilden nesile geçen feodal ahlâkta ve bunun halkta yarattığ 1 köhne zihniyette görür. Eser, Azerbaycan tiyatro tarihinde ilk defa görülen tek perdelik oyundur.

Necef Bey Vezirov'un "Daldan Atılan Daş Topuğa Deyer" komedisi, Mirza Fethali Ahundov'un "Mösyö Jordan ve Derviş Mesteli Şah" eserini andırır. Eserde, on sekiz yaşındaki kızını doktor biriyle evlendirmek isteyen Hırda Hanım'ın bu iş için yalancı, fırıldak çöpçatan kadın ve sahtekâr dervişle iş birliği yapması sonucunda içine düştüğü trajikomik hadise ele alınmıştır.

Vezirov'un 1890 'da yazdığı ancak 1893'te yayımlanan "Sonraki Peşmançlık (Pişmanlık) Fayda Vermez" eserinin konusunu köhnelikle yeniliğin çatışması kapsamında kaynana-gelin, baldız gelin münasebetleri oluşturur. Bu eser aynı zamanda Azerbaycan tiyatro tarihinde ilk defa kaynana-gelin ilişkilerini konu alan piyestir.

Vezirov'un tarihi gelişmelere paralel olarak ağalık-beylik dünyasının bozulmaya doğru gittiğini gösteren "Adı Var Özü Yok" eseri, Azerbaycan tiyatro tarihinde yeni bir mevzu ortaya çıkarır: "Ağalık, beyliğin çöküşü." Necef Bey Vezirov'un bu eserinden sonra tenkidi realizmin önemli yazarları, bu konu hakkında eserler yazmışsa da Vezirov kadar öne çıkamamıştır. Eserin isminin "Adı Var Özü Yok" olarak belirlenmesi zenginliğin, ağalığın adının kaldığı fakat özünün yok olduğu manasını düşündürmesinden gelmektedir.

\footnotetext{
${ }^{3}$ Bu kitap AMEA Fuzuli Adına El Yazmaları Enstitüsü Necef Bey Vezirov (Fond:4) arşivinde bulunmaktadır.
} 
Necef Bey Vezirov'un "Yağıştan Çıktık Yağmura Düştük” eseri, 188090'lı yıllarda Azerbaycan hayatında baş gösteren önemli olayları konu alır. XIX. asrın son dönemlerinde Azerbaycan' da özellikle Bakü'de petrole bağlı olarak gelişen ve büyüyen sanayi, Hazar denizinde ticarî gemicilik başlaması, yeni demir yolların yapılması Azerbaycan'da yeni bir hayatı oluşturur. Petrolle beraber Bakü, Rusya'ya ve farklı pazarlara balık, yün, halı gibi ürünler gönderir, buna karşılık muhtelif mallar alırdı. Bakü'de ticarî hayatın canlanması sonucunda birçok sigorta şirketi kurulmuştu. Yani Bakü 1870'li yılların Bakü'sü değildir artık. Vezirov'un bu eseri yeni hayatı bir tüccar üzerinden tasvir eder. Hacı Kamber, kapitalizmin Bakü'de ortaya çıkmasıyla yeni yeni formalaşıp içtimaî hayat meydanına çıkan ticaret burjuvasının tipik bir örneğini oluşturur.

Azerbaycan'ın ilk trajedisi sayılan "Musibet-i Fahreddin" hem Vezirov için hem de Azerbaycan tiyatrosunun gelişmesinde çok önemli yer tutmaktadır. Onu bu eseri yazmaya iten Azerbaycan hayat tarzında gelenek ve göreneklerdeki tutucu düşüncelerdir. Yazar eserde gerici düşüncelerin dehşetlerini gözler önüne serer. Eserin kahramanı olan okumuş, aydın, kültürlü, ileri görüşlü Fahreddin'in vahşi cahillik karşısında mücadelesi keskin ve eleştirel bir üslupla verilmiştir. Fahreddin, yeni hayatın nasıl olması gerektiğini simgeleyen bir semboldür; fakat karşısinda köhne zihniyet, eski adetler vardır. Vezirov, aslında Fahreddin'in üzerinden cemiyette hüküm süren köhneleşmiş ahlak kurallarını eleştirmektedir. İçeriğinde birçok mühim hususu barındıran bu eser kendisinden sonra yazılacak trajediler için önemli örnek olmuştur. ${ }^{4}$

Azerbaycan edebiyatında ilk defa petrol sanayisini konu alan tiyatro eseri "Pehlivana-i Zamane" Vezirov tarafından kaleme alınmıştır. Vezirov, "Pehlivane-i Zamane" eserini 1900'de tamamlamışsa da bu eserin mazmunu ile ilgili öncesinde bir makale yayımlamıştır. Bakü'de Rusça çıkan "Kaspi" gazetesine 1890'da gönderdiği bu yazı "Bakü'de Avukatlık" (Uzunburun Derviş, 1890: 13) adıyla yayımlanmış olup içeriği tamamen "Pehlivane-i Zamane"yi andırmaktadır. Bu makalede, Bakü'de avukatların halkı kandırmak için yaptığı oyunlar ele alınmış ve halkın cehaleti gözler önüne serilmiştir. Vezirov, bu konuyu on yıl sonra tekrar

\footnotetext{
${ }^{4}$ Daha fazla bilgi için bkz. Akın, Ü. (2018). Azerbaycan'ın Illk Trajedisi Musibet-i Fahreddin Üzerine Bir inceleme, Akademia Sosyal Bilimler Dergisi,, ss.61-73.
} 
gündeme getirmiş, "Pehlivane-i Zamane" adında eserini oluşturmuş, zamanın pehlivanları olarak sahtekâr, yalancı, ikiyüzlü vekilleri, bunlara yardım eden kâtipleri eleştiri süzgecinden geçirmiştir. "Pehlivanani Zamane" eserinde yazar, Aslan Bey'in simasında Bakü petrol-sanayi burjuvasının geçtiği yolu yani 80-90'lı yıllardaki birçok tipik özellikleri ortaya koyar.

Necef Bey Vezirov'un Bakü burjuva muhitini tenkit ettiği ikinci eseri "Vay Şeleküm Meelleküm" ${ }^{5}$ komedisidir. Vezirov'un "Vay Şeleküm Meelleküm" eseriyle "Ev Terbiyesinin Bir Şekli" eserleri arasında benzerlik görülmektedir. İkisi de bir perdelik olan bu eserlerde konu ve idea birbirlerine yakındır. İkisi de gençlerin eğitim ve terbiye meselesi üzerine yazılmıştır Yazar, bu eserinde muasır cemiyetin faydalı işlerine yardım etmekten çok, zengin cimrileri, tiyatronun önemini anlamayan Hanmirza Bey gibi câhil ve görgüsüzleri cezalandırır ve M. F. Ahundov'dan sonra bir eğitimci olarak tiyatronun büyük terbiyesini tasdik eder. Bu eserde Vezirov, eğitimsiz ve umursamaz gençlerin ahlaksız yaşam tarzına tenkit yaparak, aileleri ve gençleri uyarmaya çalışmıştır.

Necef Bey Vezirov'un burjuva cemiyetindeki ahlaksızlığı ön plana çıkaran diğer bir eseri 1911'de yazılan “Ne Ekersen Onu Biçersin”dir. Yazar bu eserinde Bakü burjuva gençliğinin tipik bir sembolü olan Sefterkulu üzerinden sosyal-ahlâkî problemleri gözler önüne serer. Vay Şeleküm Meelleküm” eserindeki Hanmirza Bey'in yerini bu kez “Ne Ekersen Onu Biçersin"de Sefterkulu alır. Bunlar 1905 İhtilâlinden sonra hayatta daha da feodalleşmiş ahlâksızlıklığı, cemiyetteki bozuk faaliyetleri gösteren, babalarının kendilerine bırakmış zenginliği hiç yolunda tüketen gençleri temsil eder. Aynı zamanda bu eserde yavaş yavaş çöken kapitalizmin izleri de yansitılır. Eserde insan emeğini küçümseyenlere, insanları ezenlere, bir karşı duruş dikkati çeker. Eserin ideasından Sovyet yönetiminin emellerine hizmet ettiği gibi bir sonuç çıkarılabilir; ancak eserin yazıldığı dönemde Sovyet hükümetinin kurulmadığını hatırlatmakta fayda vardır. Vezirov; "Pehlivane-i Zamane", "Vay Şeleküm Meelleküm", eserlerinde olduğu gibi “Ne Ekersen Onu Biçersin” eserinde de

\footnotetext{
${ }^{5}$ Bu eserin ismini oluşturan tabir, bugün Azerbaycan'da kullanılmamaktadır. Azerbaycan'da eski zamanlarda sokaklarda ve eğlence mekânlarında oynanan bir oyun havası olduğu bilgisi, Azerbaycan'ın ünlü yazarlarından Adalet Tahirzade tarafından tarafımıza verilmiştir (27.04.2017). Eserde, umursamaz gençlerin bu tür oyunlarla zaman geçirmesi tenkit edilir.
} 
kapitalist unsurların çürüdügünü göstermeye çalışır, burjuva ahlâk düşkünlüğünü ciddi tenkit ateşine tutar.

1912'de tamamladığı "Geçmişte Kaçaklar" adlı piyesi, Vezirov'un yaratıcılığında önemli bir yer tutmaktadır. Feyzulla Kasımzade N. B. Vezirov kitabında "Geçmişte Kaçaklar" eserinin 1912'de yazıldığını ve ilk olarak Kafkas valiliği Senzurası tarafından 1914'te oynanmasına izin verildiğini belirtir (Kasımzade, 1954, s.182). Eser ilk defa 1935'te Vezirov külliyatında neşr olmuştur. Vezirov, bu eserini yazarken tarihi hadiselerden istifade etmiştir. 1870-80'li yıllar, Azerbaycan'ın siyasî ve ekonomik sıkıntılar çektiği yıllara denk gelir. Bu dönemde Çar hükümetinin görevlendirdiği idareciler, bunlarla işbirliği yapan ağalar-beyler çıarları uğruna halka ağır eziyetler vermekteydi. Bu yüzden bunlara başkaldıran bazı gençler dağa, dereye kaçarak kendi gruplarını oluşturmaya başlamıştır. Zengin ağalara-beylere ve dönemin idarecilerine korku salan bu gençlerden biri de Kerem'dir. ${ }^{6}$

Necef Bey Vezirov'un Sovyet hükümetinin başa geçtiği ilk yıllarda kaleme aldığ 1 "Taze Asrın İbtidası", yazarın tiyatro eserleri arasında hususî yer teşkil eder. 1920'de Azerbaycan'da Sovyet hâkimiyetinin kuruluşu Vezirov için ümit verici bir inkılap olarak görülmüştür. Vezirov'un bu inkılapla ilgili düşüncelerinin yer aldığı ilk eser "Taze Asrın İbtidası"dır. Eserin başlı̆̆ı, sosyalist inkılap ile dünyada yeni bir dönem başladığ vurgulanmak istenir. Vezirov bu eserde "yeni kurulan bir idarenin alâmetlerini, bu dönemdeki mülkedar şuuru, zahmetkeş kitlelerin hayatında ve müterakki ziyalıların dâhili âleminde emele gelen yenilikleri" (Sultanlı, 1964, s.248) tasvir etmeye çalışır. Hüseyin Ali Han, eserde eski yönetimi, kadim zihniyeti temsil eden biri olarak karşımıza çıkar. Hüseyin Ali Han, yazarın "Adı Var Özü Yok" eserindeki Cennetali Ağa'yı, “Musibet-i Fahreddin" de Rüstem Bey'i hatırlatmaktadır. Onlar da o eserlerde yeni fikirleri kabul etmeyip köhne zihniyeti savunan anlayışın esiridir. Ancak görülür ki Hüseyin Ali Han, Azerbaycan'da yaşanan gelişmelere kayıtsız kalamaz, kabul etmek istemese de sonunda razı olmak durumunda kalır.

Görüldüğü üzere Vezirov, feodal cemiyetin kusurlarını, halkı maddi ve manevî yıkıma uğratan nedenleri, eğitimi, cahilliği, âdetleri, evlilik

\footnotetext{
${ }^{6}$ Daha fazla bilgi için bkz. Akın, Ü. (2018). "Necef Bey Vezirov ve Geçmişte Kaçaklar Piyesi” Türkiye ile Türk Dünyası Arasında Bir Köprü Yavuz Akpınar Armağan Kitabı. (Edt. Nazım Muradov, Yılmaz Özkaya) istanbul: Bengü Yayınevi, ss.766-775.
} 
sorunlarını, yobaz mollaları, dervişleri, şeyhleri, siyasî meseleleri edebî tenkidinden geçirerek tiyatrolarında anlatmaya çalışmıştır.

M. F. Ahundov ve Necef Bey Vezirov'un çizgisinden devam eden devrin önemli dramaturglarından biri de aslen Ermeni olan Vasak Medetov (1845- 1914)'tur. Medetov; Rusça, Farsça, Arapça ve Azerbaycan Türkçesini anadili gibi bilmektedir. V. Medetov, eserlerinde Azerbaycan halkının millî ve kültürel özelliklerini Azerbaycan Türkçesiyle yansıtmaya çalışmıştır. "Gırt-Gırt” (1880), “Tamahkârlık Düşman Kazanır" (1881), "Göze Görünmeyen Şal" (1882), "Bacı ve Kardeş" (1883) eserleri ile Ahundov'un yolunu sürdürmeye çalışmıştır "Gırt-Gırt" adlı bir perdeden oluşan eserinde polislerin ve memurların hayatları gülünç bir şekilde anlatılmaya çalışılır. Azerbaycan Türk'ü ve bir Ermeni aralarında sorun nedeniyle Çarlığın eyalet merkezi polisine şikâyete gelirler. Azerbaycan Türk'ü Azerbaycan Türkçesiyle, Ermeni yarım yamalak Rusçayla, Çar memuru Rusça konuşur ve aralarında dil anlaşmazlığı nedeniyle komik bir durum oluşur. Yazarın burada vermeye çalıştığı mesaj dil konusunda anlaşmazlığın yarattığı sorunlardır. "Tamahkârlık Düşman Kazanır" piyesi Medetov'un en hacimli eseridir. Aile meselelerini konu alan bu eser, Ahundov'un Mürafa Vekillerini hatırlatır. "Göze Görünmeyen Şal" piyesin konusu ise Binbir Gece Masallarından alınmıştır. Zerbeli adlı bir ustanın şah için benzeri bulunmayan bir şal dokuyarak şahı ve saraydaki yaltakçılarını kandırması ve alaya alması eserin konusunu oluşturur. Medetov, saray ahalisinin korkaklığını, iş bilmezliğini, ikiyüzlülüğünü tenkit ederken onların karşısına akıllı, cesaretli Zerbeli'yi çıkarır.

Azerbaycan hayatını, halkın yaşayış tarzını, folklorik özelliklerini ve Azerbaycan-Ermeni ilişkilerini eserlerinde anlatan Medetov, Azerbaycan modern tiyatronun gelişmesinde önemli katkılar sunmuştur (Kasımzade, 1960, s.153).

XIX. asrın sonlarına doğru Azerbaycan tiyatrosundaki gelişme, hızla devam etmiştir. Dönemin tiyatro yazarları; Azerbaycan hayatında yaşanan gelişmeleri eserlerinde işlemeye çalışmış, bu sayede ülkenin içtimâ̂, siyasî, iktisadî ve medenî hayatındaki değişmeleri halka anlatmaya uğraş göstermiştir. Bu dönemde devrin önemli tiyatro yazarlarından biri de Reşit Bey Efendiyev (1863-1942)'dir. Gori Semineryası'nda (Öğretmen Okulu) eğitim alan Reşit Bey, çocuklar için ders kitapları yazmış, şiirle 
uğraşmış ve tiyatrolar kaleme almıştır. Ayrıca Rus klasiklerinden tercüme faaliyetlerinde de bulunmuştur. Reşit Bey'in Azerbaycan tiyatrosunda önem arz eden komedisi beş perdeden oluşan "Kan Ocağı" (1880) dır. Azerbaycan hayatında yaşanan bozukları ifşa eden bu eserde küçük yaştaki kızların yaşlı erkeklere verilmesi, mollaların mektephânelerdeki çirkinlikleri, aile terbiyesi gibi birçok içtimaî bozukluk tenkit edilir. Reşit Bey'in eserin mukaddimesinde belirtmeye çalıştığı nokta, komedilerin ne amaçla kaleme alındığını göstermesi bakımından çok önemlidir:

"Hükemanin birinden sual elediler ki edebi kimden öğrendin? Dedi edepsizden. Komediya edepsizliğin aynasıdır. Bes bu güne milletimiz arasında mevcut olan edepsizliği bele bir ayna vasitasıyla meydaan koyup komediya yazmaktan maksadımız özellikle edep öğretmektir. Mesel var ki güldürenin yanına gitme, ağlatanın yanına git. Ey Türk (Azerbaycanlı) kardeşlerim, bizim bu ayıbımızı gördükçe bizim ağlamamız gerek. Bu ayıp ve noksanlardan bize danışmak gerek. Bunun için de müptela olduğumuz rezalet ve zelalet aynen müşehhes (somut) kllınıdır ki her birisi basiret sahibine büyük bir derstir." (Celal ve Hüseynov, 2000, s.337)

Aslında Reşit Bey, eserde yaşanan bozuklukların nedenini cehalette görür. Piyesin kahramanı Kerim cahildir, katildir. Küçük oğlan Murtuz hırsızdır. Komşularının horozunu, tavuklarını; mollahaneden de kitap çalmıştır. Babaları Musa, Müslümanlıktan dem vursa da evinde yaşanan her şey Müslüman yaşam tarzına karşıdır, haramdır. Reşit Bey, bu eserde eğitimsiz ailelere ve onların çocuklarına eleştiri yöneltmektedir. Aynı zamanda dönemin skolastik usulleriyle köhne eğitim veren mektephaneler de bu eleştiriden en büyük payı alır. Eserde mollahanelerin birer eğitim kurumu olmaktan çıkıp çocukları döven bir ocak gibi gösterilmesi, Reşit Bey'in okuyucuya ve izleyiciye vermeye çalıştığı mesajı içerir. Bu durum aslında dönemin aydınları tarafından hem gazetelerde hem de tiyatro eserlerinde dile getirilmiştir. Yazara göre çocuklar artık "Eti senin kemiği benim" anlayışına göre okutulmamalıdır.

"Komşu Komşu Olsa Kör Kız Ere Gider", eserinde Reşit Bey, aile hayatını konu edinir. Azerbaycan aile hayatını ele aldığı bu piyeste, Azerbaycan'ın gelenek ve görenekleri tasvir edilir. Eser aynı zamanda konusu itibariyle Şinasi' nin "Şair Evlenmesi" piyesine benzemektedir.

"Sakkalın Kerameti" eserinde Reşit Bey, düşündürücü ve dikkat çeken bir konuyu komiklikle ele alır. Hacı Söhrab üzerinden halkın molla- 
lara bakış açısını tenkit eden yazar, satır aralarında "her sakallıyı molla sanma" mesajını vererek konuyu komik bir duruma dönüştürür. Güldürürken düşündürmeyi amaçlayan eser, Hakverdiyev'in "Acından Tabip" hikâyesini andırır. 1909'da kaleme alınan bu eserde dönemin ahundlarına ve mollalarına karşı cahil halkın bakış açısı ifşa edilir. Terkeş Obasında Şahsenem'in evine sığınan sahte molla Hacı Söhrab ve arkadaşları kendilerine gösterilen ihtiramdan oldukça memnundurlar. Şahsenem'in molla Söhrab'a verdiği değer "Ayağının toprağına canım kurban ahund. Seni bize Allah gönderdi. Benim hayatım bitti, belki senin gibi müçtehit ağalarımın kulluğunda durursam bana iman verir, ben de iman sahibi olurum." (Efendiyev, 2006: s.98) cümlelerinde görülmektedir. Sadece Şahsenem değil obanın tamamı, sahte molla Söhrab'ın ve arkadaşlarının oyununu bozamamıştır. Bu durum Reşit Bey'in toplumda bu tür olayların yaşandığı kanaatini oluşturmak amacını güder.

Reşit Bey'in "Pul Delisi" piyesi adından da anlaşılacağı üzere paraya duyulan düşkünlüğün eleştirisini içermektedir. Bu eser, Necef Bey Vezirov'un Pul Düşkünü Hacı Ferec'i hatırlatır. Açgözlülüğüne engel olamayan Meşedi Muhammed'in, oğlunu güya mirasa konan Sitare'yle evlendirmeye çalışması ve bunu başarması; ama Sitare'nin mirasa konmadığı$\mathrm{n}$, bunun bir oyun olduğunu öğrendiği zaman kalp krizinden vefat etmesi eleştirel bakış açıyla anlatılır. Aslında yazar burada sadece $\mathrm{Mu}$ hammed'i değil Azerbaycan'ın bütün para ve çıkar düşkünlerini eleştirir.

"Bir Saç Telinin Kıymeti" eserinde yoksul; ancak gururlu bir ailenin yaşam mücadelesini ele alır. Babası Nizameddin'e bakmak için evlerindeki her şeyi satan son çare olarak da artık saçlarını satacak hale gelen Şefika'nın vakur duruşu, Azerbaycan kadınını simgeler. Şefika, saçlarını kestirmek üzereyken bankadan kendilerine gelen para çekiyle çok sevinir. Bu çek sayesinde babası iyileşir. Şefika da "babam iyileşmeden ben evlenmem" (Efendiyev, s.105) sözünü tutmuştur. Babası iyileşince oğlu Melikmehmed'e istemeye gelen Şahnaz Hanım, Şefika'nın "sen babama varacaksın ben de oğluna" (Efendiyev, s.112) şartıyla karşılaşır. Reşit Bey'in bu eserde dikkat çekmeye çalıştığı bir diğer nokta Nizameddin'in evlilik konusunda kızının görüşüne olan saygısıdır. Bu durum o dönem için büyük önem arz eder.

Azerbaycan'ın ilk kadın dramaturgu Sakine Hanım Ahundov (18651927) eğitimini Guba'da ve Bakü'de almıştır. Sakine Hanım, öğretmenlik 
mesleğinin yanında edebiyat ve tiyatroyla da ilgilenmiş ve birçok piyes kaleme almıştır. "Elmin Bahresi ya da Elmin Semeresi", "Gelin ve Kaynana", "Bahtsız Bala", "Zulmün Semeresi", "Hakk Söz Acı Olar", "Şahzade Ebülfez" gibi piyesleri yazmıştır. "Zulmün Semeresi" adlı piyesi Hüseyin Araplinski tarafından 1914'te Tiflis'te; Abbas Mirza Şerifzade tarafından ise 1917 ve 1922 yıllarında Bakü'de sahnelenmiştir (Rəhimli, 2003, s.6). Sakine Hanım'ın "Elmin Semeresi" piyesi Azerbaycan tiyatro tarihi için önem arz etmektedir. Piyesin okunması, rollerin paylaşımı ve gerekli düzeltmeler yapıldıktan sonra piyes, 2 Aralık 1904'te Bakü RusMüslüman Gimnaziyumu sahnesinde gösterilmiştir. Bu eser Müslüman dünyasında kadınlar tarafından sahneleştirilen ve oynanan ilk tiyatro eseridir (Merdanov, 2011, s.295). Eserde yer alan kişilerin tamam1, okuldaki kız öğrenciler ve kadın öğretmenlerden oluşmuştur. Eserin içeriği ile ilgili olarak Metane Vahid'in Nazif Qehramanlı'dan aktardığı bilgilerde "Elmin Semeresi piyesi neredeyse 'Anamm Kitabı'nı hatırlatır. Lakin bu piyes Anamın Kitabı'ndan yirmi yıl önce yazılmıştır. Elmin Semeresi piyesinde aile konflikti muhtelif dünya görüşlü aile üyeleri arasında baş verir. Böyle ki Şark Müslüman tahsili almış Nasrulla Han'la Avrupa tahsili almış Feyzulla Han arasında görünmez bir münakaşa mevcuttur. Sakine Hanım bu piyeste dramaturgiya materyalini doğru koymuş olsa da piyesteki başkahramanlarına Mirza Celil gibi büyük ihtiras ve dramatizm verememiştir." şeklinde değerlendirme yapılmıştır (Vahid, 2015: s.15). Sakine Hanım'ın sadece bu eseri değil yazdığı diğer dört piyesi de günümüze ulaşamamış olduğundan eserlerin orijinal halleriyle ilgili tarafımızca yorum yapılamamaktadır. Eserle ilgili Nazif Qehramanlı'nın verdiği bilgiler yukarıda belirtildiği gibidir. Eserlerin bugüne ulaşamamasının nedeni Sovyet döneminde uygulanan katı ve şiddetli repressiya (1920-1950) döneminin halka verdiği korkudur. Sakine Hanım'la ilgili Azerbaycan'da yapılan çalışmalar göstermektedir ki onun eserleri Sakine Hanım'ın kardeşi İbrahim Bey'in kızı Reyhan Topçubaşova tarafından yakılmıştır. ${ }^{7}$ Hacı Zeynelabidin

\footnotetext{
${ }^{7}$ Sovyetler zamanında özellikle Stalin'in repressiya dönemi olarak bilinen katı ve acımasız siyasi politikası sonucu birçok aydın sürgüne gönderilmiş ve birçoğu da kurşuna dizilmiştir. Bu yüzden halkta korku hâkim olmuştur. Sakine Hanım'ın eserleri de rejime tehlike oluşturabileceği düşüncesiyle Reyhan Topçubaşova tarafından yakılmıștır. Bu konuda şu çalışmalara bakılabilir: Irade Sarıyeva "Bir Samanın Üç UlduzuUlduz aliyeva, Sakina Axundzada ve Göyarcin Xanım", Bakı Xabar, 4 Sentyabr 2015, Matanat Vahid, "ilk Dramaturq ve Romancı Qadın" Jdabiyyat, Bakı,, 25 lyul 2015.
} 
Tagiyev'in açtığı okulun sahnesinde sergilenen "Elmin Semeresi" isimli oyun, daha sonra kız öğrencilerin velilerinden büyük tepkiler almışsa da onu amacından döndürmemiştir. Birbiri ardınca "Haqq Söz Acı Olar" eseriyle kaynana ve gelin münakaşasını ilk defa gündeme getiren Sakine Hanım, "Gelin ve Kaynana" piyesini yazar. Piyeslerin her ikisinde de kadın suretler yer alır. İzleyiciler de sadece kadınlardan ibarettir. Qulam Memmedli konuyla ilgili olarak "Azerbaycan kadınları sahne medeniyetinin güzelliğini böylece tattılar" diyerek Sakine Hanım'ın çabasını ödüllendirir (Tahirkızı, 2014: s.13). Sakine Hanım yukarıda belirtilen piyeslerin hem yazarı hem de yönetmenliğini yapmıştır. Yani o, Azerbaycan'ın hem ilk kadın tiyatro yazarı hem de ilk kadın rejisörü olmuştur. ${ }^{8}$

Dönemin önemli tiyatro yazarlarından biri de Celil Mehmetkuluzade'dir. Azerbaycan edebiyatının birçok türünde eser vermiş olan Celil Mehmetkuluzade, Molla Nasreddin imzasıyla tanınmıştır. Celil Mehmetkuluzade'nin hikâye ve romanlarındaki yaratıcılık tiyatroda da kendini bulmuştur. 1909'da yazdığı "Ölüler" adlı komedisi Azerbaycan'da büyük ilgi toplamıştır. Bu piyeste yazar, Müslümanları yaşayan bir ölü gibi görmektedir. Çünkü onları yaşadığı çağdan habersiz, ilimsiz bir işe yaramayan kişiler olarak tasvir eder. Müslümanları mensubu olduğu dini bile tam olarak bilmemekle, dini sömüren mollaların maşası olarak kullanılmakla tenkit eder. Yazar eserde, Müslümanların bu ölüm uykusundan uyanması için çözüm yolunu göstermeye çalışır. Bu anlamda dini kendi çıkarı doğrultusunda kullanan din adamları da eleştiriden nasibini almış, sonrasında Celil Mehmetkuluzade'yi gâvurlukla itham etmişlerdir. Eser hakkında Akpınar şu bilgiyi vermektedir:

"Bu komedide o dönemdeki Müslüman toplumunun hayatı onlarm diriyken ölülüğü; yüksek estetik ve büyük yürek ağrısıyla kaleme alınmıştı. Eser ilk kez 1916'da Bakü'de sahneye konulmuş, bunun ardından da Transkafkazın diğer şehirlerinde, Orta Asya'da ve İdilboyu'nda büyük başarn ile gösterilmiş ve ilgi kazanmıştır. Fanatikler ise "Molla Nasreddin" dergisindeki makaleleri ve Ölüler eseri için Mirza Celil'i yeniden ölümle tehdit etmiş; hatta onun öldürülmesi için resmî bir fetva bile verilmişti." (Akpınar, 1993, s.154)

\footnotetext{
${ }^{8}$ Daha fazla bilgi için bkz. Akın, Ü. (2018). "Azerbaycan Tiyatrosu ve Romanında Öncü Bir Kadın: Sakine Hanım Ahundzade" Filoloji Alanında Yenilikçi Yaklaşımlar. Ankara: Gece Akademi, ss. 25-33.
} 
Azerbaycan modern edebiyatının gelişmesinde önem arz eden Celil Mehmetkuluzade'nin “Anamın Kitabı (1920), Kamança (1920), Danabaş Kendinin Mektebi (1921), Deli Үĭ̆gıcağ 1 (1927)" komedilerinin zengin bir bakış açısıyla kaleme alındığını söyleyebiliriz (Ahmədov, 1960, s.564).

"Anamın Kitabı" adlı piyesinde yalnızca bir aile tasvir edilmiştir. Dört kardeşten bahsedilen bu piyeste kardeşlerin üçü erkek biri kızdır. Üç erkek kardeş de eğitimlerini farklı ülkelerde almış, en büyük erkek Rüstem Bey Rusya'da, ortanca erkek Mirza Mehemmedali İran'da, küçük erkek kardeş de Türkiye'de okumuşlardır. Celil Mehmetkuluzade, piyesinde bu üç kültürün özelliklerini satır aralarında okura vermekle birlikte asıl gayesi o dönemki Azerbaycanlı okumuş kişilerin yani aydınların fikir ayrılıklarını ortaya koymaktır. Eğitim meselesinden anadil konusuna, siyasî ve içtimaî hususlara yer veren bu piyes, Azerbaycan halkının bir yansıması olarak kabul edilebilir.

Yazarın "Kamança" adlı eseri mühim bir konuyu ele almaktadır. Azerbaycan ve Ermeni halkının anlatıldığı bu eser, aynı zamanda musikînin insan tabiatındaki tesirini gözler önüne serer. Yalnızca bir perdeden oluşan eserde şahıs kadrosu az olsa da Çar döneminin de eleştirisi yapilir.

"Danabaş Kendinin Mektebi" (Danabaş Köyünün Mektebi) adlı piyeste, yeni usulde eğitim veren mektep konusu anlatılır. Eserde ele alınan konu, Türk dünyasının bu konudaki öncüsü sayılan İsmail Gaspıralı'nın köhne zihniyetlere, dini çıkarı uğruna kullanan şeyhlere karşı verdiği mücadeleyi akıllara getirir. Yeni usulde eğitimin geri kalmış eski düşünceyi savunan bir kentte neler getireceğinin değerlendirmesi yapılir.

Yazarın son tiyatro eseri olan "Deli Yı̆̆ıncă̆ı", konusu itibariyle Ölüler komedisini hatırlatır. Bir tarafta ölüler diğer tarafta deliler yer alır. Deli Yı̆̆ıncağı komedisindeki olaylar, yaşanan döneme daha yakınlık gösterir. Bu olaylardan kasıt, İran idarecilerinin Güney Azerbaycan'da uyguladığı şiddetli yönetim anlayışı ve sömürgeci devletlerin şark halklarında kurmaya çalıştığ 1 düzendir. Görüldüğü üzere son derece önemli konuları içinde barındıran eser, Müslüman halkın yaşadığı zulümleri kendine has bir bakış açısıyla anlatır.

XIX asrın sonlarına doğru tiyatro eserleriyle dikkat çeken bir diğer isim doktor, eğitimci, devlet adamı ve yazar olan Neriman Nerima- 
nov'dur. 14 Nisan 1870'de Tiflis'te doğan Nerimanov, ilk eğitimini ailesinden almış sonra ilkokul için Rusça eğitim veren bir okula gönderilmiştir. 1882' de Gori Muallimler Seminariyasında eğitimine devam etmiş, burada dünya edebiyatı klasiklerini okuma fırsatı yakalamıştır. Bu okul onun dünya görüşünün şekillenmesinde önem arz etmektedir. 18901891'de Tiflis'in Borçalı bölgesinde öğretmen olarak görev yapmış burada halkın cahilliğini gören yazar, daha sonra gördüklerini Nadanlık adlı dram eserinde ele almıştır. Azerbaycan millî tiyatrosunun gelişmesinde büyük hizmetleri olan Nerimanov, Nadanlık (1894), Dilin Belası yahut Şamdan Bey (1899) ve Nadir Şah (1899) gibi dram eserleri kaleme almıştır. Özellikle Nadir Şah adlı dramı Azerbaycan'da büyük yankı uyandırmıştir.

Nerimanov'un "Nadanlık" eseri ilk kalem tecrübesidir. Eserin ideası "cahilliğe karşı mücadele yürütmek" olarak açıklanabilir. Nerimanov'un Dilin Belası yahut Şamdan Bey eseri, burjuva cemiyetinin doğurduğu felaketleri Şamdan Bey üzerinden ele alır. Nerimanov bu eserde kapitalizmin yol açtığı sorunları göstermekle kalmaz; aynı zamanda bunun sebeplerini ortaya koyar.

Nerimanov'un "Nadir Şah" isimli dramı tarihî bir olaya dayanmaktadır. Bu eserde Nerimanov, Şark halklarının siyasî, içtimaî ve medeni ilerlemesinde mutlak monarşik hâkimiyetin artık bittiğini göstermeye çalışır. İran'ın tarihi geçmişini nazara alan Nerimanov, Nadir Şah'ı tüm yönleriyle vermeye çalışır. Nadir Şah'ın hayata geçirmek istediği demokratik mahiyetteki idea ve islahatların mutlak hâkimiyette mümkün olmadığını göstermesi, o dönem için çok önemli meseleyi ortaya koyar. Eserin sonunda Nadir Şah'ın hayatını bu yolda kaybetmesi, çarlığın usul ve idaresine bir karşı çıkışı gösterir. Nerimanov'un bu eserinde 18. yy hadiseleri tasvir edilse de 19. yy'ın içtimaî ruhu, baskıdan sıkılmış, esaretten yılmış bir halkın uyanma hareketleri de ifade edilmeye çalışılır.

Azerbaycan modern tiyatrosunun gelişmesinde mühim rol oynayanların başında yer alan bir diğer simâ Abdurrahim Bey Hakverdiyev (1870-1933)'dir. XIX. yüzyılın sonlarından itibaren dram eserleriyle profesyonel edebî faaliyete başlayan Hakverdiyev, bu dönemden önce Rus edebiyatında birkaç kısa tercüme de yapmıştır. Yazarın üç perdeden oluşan "Yeyersen Gaz Etini Görersen Lezzetini" (1892) adlı ilk komedisinde bir tüccarın ailesinde yaşanan gülünç olaylar anlatılır. Ayrıca çok 
eşlilikle evlilik, yazar tarafından tenkit edilir. Yazar, Azerbaycan tiyatro tarihinde çok önemli görünen "Dağılan Tifak" (1896) piyesinde beylerin ve ağaların yaşamını konu edinmiştir. XIX. yüzyılın sonlarına doğru Karabağ'daki yüksek zümrenin yaşadığı sosyal sorunları anlatılır. Buradaki beylerin, ağaların ve onların aile fertlerinin yaşam tarzı yazar tarafından eleştirilir. Hakverdiyev'in bu eserde yüksek zümrenin iç yüzünü ortaya koymasına rağmen Sovyet döneminde birçok araştırmacı, yazarın bu eserdeki olaylara bakış açısını beğenmemiştir. "Dağılan Tifak", yazarın en başarılı dram eserlerinden biri olarak gösterilmektedir. Oyun ister Çarlık Rusya'sı döneminde isterse de Sovyetler Birliği döneminde en çok sahneye konulan eserler arasinda yer alır (Akhmadov, 2016, s.72).

Hakverdiyev'in iki yıl gibi uzun bir sürede kaleme aldığı $A \breve{g} a M e-$ hemmed Şah Kaçar 1907'de tamamlanmıştır. Bir trajedi olan bu eserde, yazar tarihi şahsiyet olan Ağa Muhammet Şah Kaçar' $1^{9}$ olduğu gibi tasvir etmeye çalışmıştır. Yazar olayları ele alırken olabildiğince gerçekçi yönlerden yaklaşmıştır. Abdurrahim Bey Hakverdiyev bu tiyatro eserini, Petersburg ve Mazenderan şehirlerinde uzun müddet süren araştırmalarından sonra kaleme alır. Eserde, Nadir Şah'ın ölümünden sonra İran'da yaşanan siyasi krizin başlaması ve Ağa Muhammed Han Kaçar'ın bu durumdan yararlanarak hâkimiyeti ele almasından bahsedilir.

Ahundov'un yolundan giden Abdurrahim Bey Hakverdiyev 1911'de ona ithaf ettiği "Heyalat" piyesini yazmıştır. Bu piyeste yazar Mirza Fethali Ahundov'un hayatını anlatır. Onun milleti uğruna yaptıkları ve yapmaya çalıştıkları ele alınmıştır. Hayaller anlamına gelen bu eserde Hakverdiyev, Ahundov'un mensubu olduğu Azerbaycan halkındaki hayalleri ele almıştır. Ahundov, halkının kadim zihniyetten uzaklaşmasını istemiş, modernleşmek için halkı gayrete çağırmıştır. Eserde yer alan kahramanlar, Ahundov'un eserlerindeki başkişilerdir. Bu kişiler Ahundov'un eserlerinde tenkit edildikten sonra Hakverdiyev'in de eleştiri süzgecinden geçmiştir.

Abdurrahim Bey'in son dönemde kaleme aldığ tiyatro eserleri Bolşeviklerin yönetime geldiği 1920'den sonrasına rastlar. Yazarın Sovyet dö-

\footnotetext{
${ }^{9}$ Kaçar Hanedanlığı, Iran'da hüküm sürmüş ve iki yüz yıl şahlık yapmış olan Azerbaycan Türklerinin bir soyunun adıdır. Kurucusu şah Muhammet Kaçar'dır. Konu hakkında geniş bilgi için bkz. Sarı, i. (2016). Türk'ün Savaşları: Türklerin islam Dünyasındaki Liderliği ve Savaşları, Net Medya Yay., İstanbul, 2016, s. 113.
} 
nemindeki eserlerinin kahramanları artık bey ve ağaların zulmünden kurtulmuş köylüler ve genç aydınlardır. Bu dönem eserleri içinde en kuvvetlisi “Köhne Dudman"(1927)dır. Tarihî bir tiyatro eseri olan “Köhne Dudman" da XIX. Yüzyıl Azerbaycan'ındaki hanlıklar ve burada cereyan eden olaylar ele alınmıştır. Daha sonra yazar, "Baba Yurdu" dramını, Köhne Dudman"ın devamı olarak yazmıştır. Burada da köylülere zulmeden köy ağası Cihangir Ağa karakteri vardır. Eserin sonunda köylüler ona karşı isyan etmiş ve onunla diğer ağaları ve beylerin mal varlığını ele geçirmişler. Burada yazarın Sovyet düşüncelerine uygun olarak son kısımda köylülerin galibiyetini ön plana çıkardığ dir (Uygur, 2005, s.4).

Yazarın tiyatro alanında yukarıda belirtilen eserleri dışında "Kimdir Mügessir", "Aç Herifler", "Kırmızı Karı”, "Padişahın Muhabbeti”, “Ağaç Gölgesinde”, “Koca Tarzan”, "Vaveyla”, "Sahne Kurbanı”, “Meşedi Kulam Kıraat Öğrenir", "Kadınlar Bayramı", "Kamran” "Sağsağan”, "Yoldaş Koroğlu", "Çok Güzel”" gibi küçük çaplı piyesleri de bulunmaktadır.

Azerbaycan tiyatrosunda isim yapmış önemli kişilerden bir diğeri de Süleyman Ahundov (1875-1939)'dur. Süleyman Sani Ahundov da Necef Bey Vezirov gibi tiyatro hayatına, Mirza Fethali Ahundov'un "Hacı Kara" adlı tiyatrosunun tesiriyle 1899' da yazdığ "Tamahkâr" komedisiyle girer. Bu piyesinde yazar, dönemin birtakım bozukluklarına karşı çıkmış; yeni hayat düşüncesini eserinde işlemiştir. Realist tarzda kaleme alınan bu eser yazıldığı dönemde ilgiyle karşılanmıştır.

1906' da burjuva cemiyetini ele aldığı küçük piyesleri "Dibdat Bey" ve "Türk Birliği"ni yazmıştır. Bu eserlerde yazar, siyasetçilere Mollanasreddinciler gözünden bakarak olaylara satirik açıdan yaklaşır.

S. Ahundov'un yaratıcılığı Bolşeviklerin yönetime geçmesinden sonra artmıştır. O, Sovyet devri Azerbaycan tiyatrosunda ilk dram olan "Laçın Yuvası" nı 1921'de kaleme almıştır. Eser yeni hayatla köhne hayatın karşılaştırmasını yaparken halkın menfaatlerini ön plana çıkartır. Eserin sonunda yeniliğin gericiliğe karşı galip gelir. Ayrıca bu eser, Sovyet hâkimiyetinin kurulmasının yıldönümü münasebetiyle piyes yazmak için ilan edilen devlet müsabakasında birinci seçilir.

"Çarhı-felek" (1921) piyesinde yazar, çıkarları uğruna halkı ezen istismarcıların inkılabî hareket neticesinde devrilmesini sembolik bir tarzda ele alır. Yenilikle köhneliğin karşılaştırılmasının yapıldığı "İki Yol” 
(1922) piyesi yeni hayatın güzelliklerini vurgulamaktadır. Tiyatroyu halka sevdirme ve halkı bilgilendirme amaçlı kullanmayı amaç edinen Memmed'in buna karşı olanlarla mücadelesi de eserin dikkat çekici tarafidır.

"Aşk ve İntikam"(1922) adlı beş perdeden oluşan piyesi realist tarzda yazılmıştır. Eserin konusunu Bolşevik İnkılabından önceki Azerbaycan'da, insanları felakete sürükleyen köhne adetler, zengin beyler, haksızlığa karşı gelen kişilerin mücadelesi oluşturur (Ahundov, 2005, s.7). Eserde zengin zümresinin (bey-ağa) her şeyi elde edebileceğine olan inanca karşı çıkış vardır. Yazar bu eserde Şahbaz Bey'in üzerinden paranın, mülkün, eski adetlerin aileleri faciaya sürüklediğini göstermeye çalışır. Feodal ve ahlaksız burjuva zihniyeti günahsız insanların da yok olmasina neden olur.

Geçmişten gelen eski adetlerin eleştirisinin yapıldığı, yeni hayatın kurallarının köhne normlardan üstün olduğunu anlatan diğer piyesleri de Karanlıktan Işı̆̆a" (1921), "Molla Nasreddin Bakü'de" (1921), "Şahsenem ve Gülperi” (1921), "Bir Aşkın Neticesi" (1922), "Yeni Hayat" (1923) tır. Tiyatro yazarlığın yanında hikâyeleri de olan Süleyman Ahundov burada da halkın sorunlarını, 1905 ve 1917 ihtilâllerini, insanların psikolojik durumlarını işler.

Onun "Molla Nasreddin Bakü'de" piyesi C. Mehmetkuluzade'ye ithaf olunmuştur. Süleyman Sani ilk defa Molla Nasreddin'i sahneye çıarır. Onun cahilliğe, köhne zihniyete, hurafelere karşı satirik duruşunu gösterir. Cahilliğe vurgu yaptığı bir diğer eseri olan "Şahsenem ve Gülperi" de kadınlarla köhne zihniyetli erkekleri karşılaştırır. Süleyman Sani'nin "Bir Aşkın Neticesi" piyesi de toplumda yaşanan sosyal bozukluğu ifşa etmek üzerine kaleme alınmıştır.

Süleyman Sani, Sovyet ideolojisiyle başlayan yeni hayata vurgu yapan diğer eseri de eserin konusuna uygun "Yeni Hayat"tır. Bu piyeste yazar, ailede ve sosyal yaşamda getirilen değişikliklerin halkça ve din adamlarınca kabul edilmesi gerektiğini anlatmaya çalışır. Yeniliğe karşı çıkanlar yazarın eleştirisine maruz kalmıştır. Eserin mazmunu Necef Bey Vezirov'un "Taze Asrın İbtidası"nı hatırlatır.

Asıl mesleği öğretmenlik olan Abdulla Şaik (1881-1959) aynı zamanda tiyatro yazarı ve şairdir. Şiirlerinde hürriyet, adalet, eğitim ve millî tarih konularına yer veren sanatçı; tiyatrolarında da aynı çizgide ilerlemiştir. 
Öğrenciler için yazdığı ders kitapları yeni yetişen nesil için çok önemli rol oynamıştır.

Çocuklar için yazdığı "Eloğlu", "Vatan", "Fitne", "Nüşube", "Şah Abbas", "Karaca Kız", "Koç-Polat", "Taptıg Dede" piyesleri Azerbaycan çocuk tiyatrosunun temelini oluşturmuştur.

Çocuklar için yazdığı piyeslerin yanında "Güzel Bahar" (1910), "Bir Saat Hafiyelik" (1911), “İdeal ve İnsanlık" (1914), “İlırım” (1927), “Aldanmış Ulduzlar" (1928), "Ana" (1945) gibi Azerbaycan hayatından izler taşıyan piyesler de kaleme almıştır. "İdeal ve İnsanlık" piyesinde sanatçı ideal bir insanlığı arzulamaktadır. Eserde yer alan kişilerin isimleri tesâdüfî değildir. İsimler bile bu anlamda bize bilgi vermektedir, İnsanlık, İdeal, Merhamet, Vicdan, Adalet, Şeytan, Zulm ve Felaket.

Yazmış olduğu eserleriyle Azerbaycan Türkçesinin de gelişmesine katkıda bulunan Abdulla Şaik, Azerbaycan edebiyatında çok yönlü bir sanatçı olarak kabul edilmekle birlikte daha çok şairliğiyle ön plana çkar. Ancak sanatçının yirminin üzerinde piyesinin olduğunu da belirtmek gerekir.

Azerbaycan edebiyatının XX. yüzyıldaki önemli şahsiyetlerden biri de Hüseyin Câvid (1882-1941)'dir. Eserlerinde kullandığ1 dil Azerbaycan Türkçesi ve Türkiye Türkçesi arasında bir köprü vazifesi görmüştür. İstanbul Üniversitesinde eğitim alması onun eserlerini oluştururken kullandığı dilde etkisini gösterir. Romantik bir şair olmasına rağmen eserlerinde realizmin etkisi de güçlüdür. Şiirlerinde Abdulhak Hâmid, Rıza Tevfik, Mehmet Akif Ersoy, Tevfik Fikret'in tesiri hissedilir. Devrin siyasî ve içtimaî durumu şair ve yazar Câvid'i zaman zaman umutsuzluğa ve içe kapanıklığa çekmişse de kendi milletinin değerlerinden uzaklaşmamıştır. Câvid, 1910'da ilk piyesi "Ana"yı yazar. Piyes manzummensur karışık bir şekilde kaleme alınmıştır. Eser 1913'te tiyatronun merkezi konumunda olan Tiflis'te yayımlanır. Oyunun konusu her ne kadar İtalyan hikâyelerinden alınmışsa da yazar onu Azerbaycan-Türk maişetine uygun hale getirerek orijinallik ve yerellik kazandırır. Yazar, eserin konusunu Dağıstan hayatından almıştır. Bu eser, genç şairin ileride mükemmel bir tiyatro yazarı olacağının göstergesi sayılabilir. Yazar bu eserde oğlunu öldüren kişiyi, bilmeyerek evinde saklaması ve öğrendiğinde de verdiği sözden dönmeyen güçlü ve güvenilir bir anne karakterini ön plana çlkarır. 
1912' de kaleme aldığ1 ikinci eseri "Maral" dört perdeden oluşmuş bir piyestir. Bu eserde evlilik sorunu işlenir. Yazar eserde, çocuk yaşta denebilecek kız çocuklarının zorla evlendirilmesi konusunun hangi sonuçları doğuracağını anlatmaya çalışır. Ayrıca kadınların böyle önemli kararlarında bağımsız olabileceği düşüncesi eserin temasını oluşturur. Yazıldığı dönemde bu tür düşünceleri dile getirmek zor olsa da Cavid bu konuyu korkusuzca ele almayı başarmıştır. Eserin başkahramanı olan Maral, güçlü özellikte verilmiş bir karakteri simgelese de geleneklerin kadına koyduğu kuralları ve tabuyu yıkmayı başaramamıştır. Aslında Maral, Müslüman kadınının razı olmak zorunda kaldığı bazı adetlere karşı çıkmıştır; ancak geçmişten bugüne gelen geri zihniyetin ürünü kurallara engel olamamıştır. Yine de bir başkaldırı olarak Maral'ın bu tutumu bir sorgulamayı beraberinde getirmiştir. On altı yaşında Maral'ın kendisinden hayli yaşlı olan Turhan Bey'le zorla evlendirilmesine karşı yürüttüğü mücadele, yazarın Müslüman kadınının özgürlüğe olan tutkusunu ortaya koyar.

Cavid, 1912-1914 yıllarında üzerinde çalıştığ1 "Şeyh Senan" isimli romantik piyesini bitirir. Bu eserin konusu Kafkasya'da halk arasında yaygın olan bir efsaneye dayanmaktadır. Bu efsane büyük bir aşk hikâyesine dayalıdır.

Cavid, romantizmden kaynaklanan geleneksel konulara başvurmakla beraber, Doğu ve Batı ilişkileri gibi önemli çağdaş sorunları da "Uçurum" (1917) piyesinde kaleme almıştır. Yazar bu piyesi, İstanbul'da bulunduğu dönemdeki gözlemlerinden yola çıkarak yazmıştır. Konusu her ne kadar İstanbul hayatından alınmış olsa da geniş perspektifte Türk dünyasını Doğu ve Batı kıyaslamasıyla değerlendirmeye tâbi tutar.

Cavid'in "İblis" adlı dramı 1918'de bitmişse de 1924'te basılmıştır. Bilindiği üzere Hüseyin Cavid, Azerbaycan'da Ermeniler tarafından yapılan katliamda esir düşmüş, şans eseri ölümden kurtulmuştur. Abdulla Şaik, bu konuyla ilgili "Hatıralarım" kitabında Cavid'in İblis eserini bu acı olayın kendisinde bıraktığı tesir üzerine kaleme aldığını söyler (Babashova, s.271).

Sovyet döneminde kaleme aldığı diğer önemli eseri "Peygamber" (1922) dir. Bu eserinde yazar peygamber efendimiz Hz. Muhammed'in hayatını ele almaktadır. Yazar eserde konuyu büyük bir titizlikle ele almaktadır. Eser, ilk sahne Biset, ikinci sahne Davet, üçüncü sahne Hicret 
ve dördüncü sahne Nusrat olmak üzere dört bölümden oluşmaktadır. Eser Hz. Muhammed'in peygamber olarak seçilmesi anından İslam'ın zafer kazanması, yayılması ve genişlemesi dönemine kadarki aşamalarını kapsar. Eser tarihî olgularla zengindir, tarihî gerçekleri içerir. Cavid, eserin sonuna kadar -Sovyet dönemi olması nedeniyle- saygısızlık olmaması adına peygamber efendimizin ismini söylemeden sadece Peygamber diye nitelendirmiştir. Bu eser için Hüseyin Câvid'in kızı Turan Câvid, babası ile ilgili yazılan bir kitabın ön sözünde şöyle demektedir:

"... Yeri gelmişken Hüseyin Cavid'in "Peygamber" eseri ile bağh birkaç kelam etmek isterim. Tavsiyem özellikle tiyatrolarımıza aittir. Cavid "Peygamber" dramın sahne için yazmamışt ve eserin sahneye koyulmamasında ısrarlıydı. Bunu dikkate almanizı isterim." (T. Cavid, 2005, s.7)

Hüseyin Câvid'in 1925'te mensur olarak kaleme aldığı diğer önemli piyesi “Topal Teymur” dur. Yazar piyeste büyük Türk hükümdarı Topal Teymur'un hayatını ele alır. Hüseyin Câvid, bu oyunda Teymur'un yaptığ1 birçok seferi anlatmış, özellikle Anadolu seferi üzerinde durarak bunun yanlışlı̆̆ını vurgulamıştır. Büyük Türk hükümdarı Topal Teymur, bu eserde bütün ihtişamı ile okuyucuya tanıtılmıştır. Büyük bir beğeni ile izlenen bu piyes, Sovyetlerin engellemesine kadar birçok kez sahne almıştır (Tekiner, 1987, s.111). Hüseyin Cavid, iki Türk komutanının birbirleriyle savaşmasını yanlış bulmaktadır. Savaşı kazanan Teymur'un Beyazıt'ı esir alması sahnesi anlatılırken ona esir muamelesi yapmaması, tarihi olayın tekrar incelenmesi gerektiğine vurgu yapar. Ayrıca piyesin sonunda Teymur'un Beyazıt'a son sözleri zafer edası içinde söylememiş olması da yazarın dikkat çekmeye çalıştığı bir diğer noktadır:

"Hiç merak etme, hakanım! Sen kör bir abdal, ben de deli bir topal! Eğer dünyanın zerre kadar değgeri olsaydl, yı̆̆ın yı̆̆ın insanlara, ucu bucağı yok memleketlere senin gibi bir kör, benim gibi bir topal musallat olmazdı." (Cavid, 2005, s.302)

Hüseyin Cavid, diğer fikirdaşları gibi Türk tarihini; şan şeref kaynağı, iftihar membal, üstünlükler sergisi olarak görmüş, Türk'ün Türk'e düşmanlığını, aralarındaki çekişmeleri, Türk milletinin bütünlüğüne vurulan bir darbe şeklinde değerlendirmiştir. "İblis", "Topal Teymur" gibi eserlerindeki belirgin sahneler, bu mülahazaları tasdik etmektedir. Türk hükümdarları arasında meydana gelen kanlı çarpışmalar acı bir esefle 
yâd edilmiştir (Kengerli, 2008, 321). Hüseyin Câvid'in bu eserleri dışında "Afet" (1906-1909), "Knyaz-Deli Knyaz" (1929), "Siyavuş" (1932), "Hayyam" (1935), “İblis'in İntikamı" (1937), “Telli Saz" (1930) gibi tiyatro eserleri de vardır. Genel anlamda tiyatro eserlerine bakıldığında yazarın sadece kendi ülkesinin sorunlarını değil birçok önemli hususu (din, kadın, eğitim vs.) geniş perspektifli bir bakış açısıyla değerlendirdiğini görmekteyiz.

Azerbaycan milli marşının bestecisi de olan Üzeyir Hacıbeyov (18851948), Azerbaycan kültürel hayatında büyük rol oynamış aydınlar arasında yer almaktadır. Yazar ve gazeteciliği yanında bestekâr da olan Hacıbeyov, üç mesleğin de hakkını vermesini bilmiştir. Üzeyir Hacıbeyov; Çarlık, bağımsız Azerbaycan ve Sovyet dönemlerinde birçok eser kaleme almış olmakla birlikte, onun en başarılı eserlerini verdiği dönemler, 1905 Rusya'da yaşanan ihtilâl sonrasında baskısının azaldığı ve 1918 Azerbaycan Cumhuriyeti'nin kurulduğu dönemlerdir. İlk eserlerini opera ve operet türünde veren Hacıbeyov, bağımsız Azerbaycan Cumhuriyeti (1918-1920) dönemlerinde gazetelerde yayımladığı yazılarıyla edebi faaliyetlerini sürdürmüştür. 1908'de Azerbaycan'ın öncü aydınlarından olan Hasan Bey Melik Zerdabi'nin yönlendirmeleriyle yazdığı Leyla ve Mecnun adlı operası, sadece Azerbaycan'ın değil tüm Doğu dünyasının ilk operası olma özelliğini taşımaktadır. Bestelendiği ve sahnelendiği vakitte adından çok söz ettiren bu eser, bir aşk hikâyesinin modern bir tarzda millî özelliklerle çağdaş edebiyata uyarlanışını gösterir. "Leyla ve Mecnun" operasıyla büyük başarı kazanan Üzeyir Hacıbeyov'un ünü kısa sürede tüm Doğu ve Türk ülkelerine yayılmıştır.

1909 yılında "Şeyh Senan" operasıyla "Er ve Arvad" müzikli komedisini yazıp bestelemiştir. "Er ve Arvad" piyesi, kadın ve erkek kıyaslamasında erkek egemen zihniyeti tarafından kadının geri, hor görülmesine bir tepki olarak ele alınır. Üzeyir Hacıbeyov, piyeste erkeklere iyi bir ders vererek kadınların zekâlarını ön plana çıarmıs, evlilik kurumunun yükümlülüklerini sadece kadınlara değil erkeklere de yüklemiştir. Yazıldığı dönemde kadının toplumdaki rolü açısından önem arz eden bir piyestir.

Hacıbeyov, 1910 yılında "Rüstem ve Söhrab" operasının yanı sıra ilk oynandığı günden itibaren Azerbaycan ve bütün Doğu sanatında derin tesirler bırakan "O Olmasın Bu Olsun" müzikli komedisini meydana 
getirdi. Bu müzikal komedi eserinde vaka, Meşhedî İbad adında hayli yaşlı ve zengin bir karakterin etrafında geliştiği için eser, çoğu zaman "Meşhedî İbad" adıyla da anılmıştır. Eserleri birbiri ardınca sahnelenip büyük beğeni topladıkça, sanatçı yeni eserler üretmek için daha da motive olmuş; 1912'de "Şah Abbas ve Hurşidbanu" ile yine aynı yıl tamamlanan "Aslı ve Kerem" operaları, 1913 yılında "Arşın Mal Alan" müzikli komedisi sanatçının imzasını taşıyan yeni eserler olarak ortaya çıkmıştır. 1915 yılında ise "Leyla ve Harun" operası Hacıbeyli tarafından Azerbaycan sanatına kazandırılmıştır (Keskin, 2011, s.9).

Leyla ve Mecnun operasından sonra Üzeyir Hacıbeyov'un en çok beğenilen ve dünyanın birçok ülkesinde sahnelenen eserleri, "O Olmasın Bu Olsun" ile "Arşın Mal Alan" operetleridir. Bu operetler filmlere de uyarlanmış, halk tarafından büyük rağbet kazanmıştır. Konuyla ilgili Türkiye Dışındaki Türk Edebiyatları Antolojisi'nde şu bilgilere yer verilmiştir,

"... Ayn zamanda "O Olmasın, Bu Olsun" ve "Arşın Mal Alan" müzikli komedilerinden uyarlanarak dünya ekranlarına çıkarılan başarılı, güzel filmler çekilmiştir. Bu eserler kelimenin tam manasıyla, Azeri Türklerinin hayatına girmiştir. Oradaki birçok deyimler, bir atasözü gibi halkın ağzına yerleşmiştir. Bu operattalardan birkaç aryayı kolaylıkla mırıldanmayı başarmayan Azerî Türk'ü bulmak belki de mümkün değildir." (TDA, 1993, s.311)

Yazarın "O Olmasın Bu Olsun" piyesinde vermeye çalıştığı mesaj kadına bakış açısı ve evlilik konusunda toplumun takındığı tavırdır. Aslında "Er ve Avrad" piyesinde de ileti benzer özelliktedir. Üzeyir Hacıbeyov, "Arşın Mal Alan" piyesinde görücü usulüyle evliliğin yanlışlığına vurgu yapar. Türk edebiyatında Şinasi tarafından yazılan "Şair Evlenmesi" tiyatroda da aynı konunun eleştirisi yapılmıştır. Üzeyir Hacıbeyov'un ısrarla üzerinde durduğu kadın-erkek eşitliği, evlilik, kadın hürriyeti konuları, modernleşmenin ve toplumsal ilerlemenin esas kaynağ 1 olarak görülmektedir. Bu sorun ancak bu problemlerin halledilmesiyle çözülecektir.

Üzeyir Hacıbeyov'un eserlerin hemen hepsinde Azerbaycan halk hayatının yansımaları görülür. Sadece Azerbaycan'da değil Sovyetlerin birçok yerinde, İran'da Türkiye'de bile sahnelenmiştir. Bu konuda Akp1nar, 1919'da Türkiye'ye gelen Azerbaycanlı bir tiyatro topluluğunun 
"Meşedî İbad" (O Olmasın Bu Olsun) ile "Arşın Mal Alan" eserlerinin İstanbul'da sahnelendiğini belirtir (Akpınar, 1994, s.62).

1937'de tamamladığı "Köroğlu" operası onun bestekârlığının zirvesi olarak görülmekte ve bu eserin ona dünyada büyük bir şöhret kazandırdığını da belirtmek gerekir. Azerbaycan toplumunun kahramanlıklarla dolu şanlı ve zengin tarihini, halkın haklı mücadelesini, büyük fedakârlığını anlatan bu eser geçmişle gelecek arasında bir köprü görevi görmektedir.

Üzeyir Hacıbeyov'un eserlerinde Azerbaycan millî değerlerin, hayat tarzların ön plana çıkarıldığını söyleyebiliriz. Eserlerde verilen tenkitlerin Azerbaycan halkına birer mesaj niteliği taşıdığı da tartışma götürmeyen bir gerçektir. Bolşeviklerin Azerbaycan'ı ele geçirmesiyle oluşturdukları güdümlü edebiyatın esiri olmamak için önemli mücadele gösteren Hacıbeyov, Sovyet idaresi altında; "Köroğlu" operası, birkaç küçük beste, müzikle ilgili birkaç eser ve Sovyet rejimi için bestelemek zorunda kaldığ1 birkaç marş ortaya koymuştur. Bu mücadelede Azerbaycan'ın millî sazı olan tar'ı, simge olarak kullanır. Operalarında çaldırdığı tar'1 Azerbaycan'ın kültürel bir ögesi olarak kullanması, Azerbaycan millî musikisinin unutturulmaması açısından oldukça önem arz etmektedir.

Şiir, hikâye ve özellikle dram alanında tanınan Cafer Cabbarlı (18991934) otuz beş yıllık kısa ömründe çok sayıda eser vererek Azerbaycan edebiyatında simge şahsiyetler arasında yer almıştır. XX. yüzyıl başlarında Azerbaycan tiyatrosunun gelişmesinde müstesna hizmetleri olmuştur. Her ne kadar ilk edebî denemelerini şiirle yapmışsa da tiyatro türünde kendini geliştirmiş ve çok başarılı eserler ortaya koymuştur.

Cabbarlı ilk dramı "Vefalı Seriyye Yahut Göz Yaşı İçinde Gülüş"ü 1915 'te yazmıştır. Eser birbirlerini seven Seriyye ve Rüstem'in birbirlerine kavuşmak için yürüttügü mücadele üstüne kurgulanmıştır. Cabbarlı eserde Azerbaycan'da yaşanan sosyal adaletsizliğe, kadın eşitsizliğine din istismarına ve cahilliğe de vurgu yapar.

Cabbarlı bir yıl sonra tamamladığı "Solgun Çiçekler" (1917) adlı dramında da ilk dramında olduğu gibi sınıf çatışmalarını (zengin-yoksul, güçlü-zayıf) somutlaştırarak okuyucuya realist bakış açısıyla sunmuştur. Eserde, kapitalist anlayışın sonuçlarını göstermeyi amaçlayan Cabbarlı, insanların çıkarları uğruna her şeyi yapabileceğini eleştirel bir bakış açısiyla ele alır. 
1916'da başlayıp 1918'de tamamladığı "Nasreddin Şah" dramında Cabbarlı, İran'da baş gösteren siyasî, içtimâ̂ sorunlara yer vermiştir. İran'1 yöneten Nasreddin Şah'ın öldürülmesi, halkın isyanı olarak görülmüş; yazar tarafından adaletsizliklere, zulüm eden idarecilere bir tenkit yapılmıştır.

Türkiye'de ve Azerbaycan'da baş gösteren önemli bazı siyasî ve içtimaî meseleler Cafer Cabbarlı'nın eserlerini oluşturmada kaynak görevi görmüştür. Türk tarihinin önemli mücadelelerini eserlerine konu almış; 1917-1918'de "Trablus Muharabesi veya Ulduz", "Edirne'nin Fethi" 1919'da da "Bakü Muharebesi" adlı tarihi dramlarını yazmıştır. "Bakü Muharabesi" adlı dram kaybolmuştur. "Trablus Muharebesi" ve "Edirne'nin Fethi" dramları adından anlaşılacağı üzere Türklerin tarihinden bir kesit sunar okuyuculara. Bu dramlar Sovyet hâkimiyetinden önce defalarca sahnelenmiş; fakat Sovyet yönetimi iktidara gelince milliyetçi unsurlar taşıdığı gerekçesiyle dersliklerde okutulmamış ve sahnede oynatılmamıştır.

Azerbaycan'ın Bolşevik idaresine geçmeden önce kaleme alınan “Trablus Muharebesi" ve “Edirne'nin Fethi" dramları Türklüğü yücelttiği ve Türk mücadelesini anlattığı için Sovyetler döneminde pek kıymetli bulunmamıştır. Aslında 1924'e kadar birçok kez oynanan bu eserler verdiği mesajlardan dolayı yasaklanmış ve edebî değeri yüksek görülmemiştir. Bu durumun oluşmasında Cabbarlı'nın Sovyet platformasını kabul etmiş olması da bir gerekçedir. Cabbarlı'nın Sovyet işgalinden sonra sanatını Marksist anlayışa göre biçimlendirmesi ilk dönem eserlerini diğerlerinden ayrı tutulmasına neden oluşturur.

Azerbaycan'da Sovyet hâkimiyeti (1920) kurulduktan sonra Cafer Cabbarlı, bu yönetimi hiç tereddüt etmeden kabul etmiş ve ömrünün sonuna kadar da bu iktidara sadık kalmıştır (Arif, 1954, 29). Yazarın ikinci dönem sanat anlayışı içinde kaleme aldığı "Aydın" (1921) piyesi, sosyalist düşüncenin tesiri altında kaleme alınmıştır. Cabbarlı "Aydın" piyesinde toplumsal bir hareket olarak işçi, ezilen sınıfının hak arayış mücadelesine girdiğini duyurmaya çalışır. Aydın'ın mutluluğu için kendini feda eden eşi Gültekin'in aşk hikâyesi, kapitalizmin acımasızlı̆̆yla eserde işlenmiştir.

1880'li yıllardan sonra Azerbaycan'da tiyatroda bir canlanma görülmüşse de birtakım sorunlar yüzünden beklenen atılım gerçekleşmemiş- 
tir. Ekonomik sorunlar, toplumun tiyatroya bakış açısı, oyun sahnelenmesinde gerekli araç gereçlerin sağlanamaması, oyuncuların ücretleri, yerli kadın oyuncu bulunamaması gibi sıkıntılar tiyatronun gelişmesinde engel oluşturmaktaydı. Sorunların farkında olan Cabbarlı, tiyatronun toplum tarafından benimsenmesi ve Azerbaycan kadınlarının tiyatroya katılımları sağlanması için "Oktay Eloğlu" (1921) piyesini kaleme alır. Piyes, tiyatro oyunlarının sahnelenmesinde ortaya çıkan sorunlar ve toplumdaki yanlış tiyatro algısı üzerine kuruludur. Cabbarlı "Oktay Eloğlu" oyununda tiyatroyu halka kabul ettirmeye kararlıdır. Eserde geçen "Halkla oyuncak gibi oynanmaz. Bugün çıkmazsak, yarın kimse kapımızdan geçmez. Bir kişi de olsa, oynanmalıdır." (Cabbarll, 2005, 243) sözleri ve salon kirasını vermeden tiyatroyu oynayamayacaklarını söyleyen salon sahibine yüzügünü vererek yine de piyesi oynatmak istemesi bunu gösterir niteliktedir.

Cabbarlı'nın Azerbaycan'ın IX. yüzyılda Araplar tarafından işgal edilmesi sonucunda zulme ve adaletsizliğe karşı başlayan mücadeleyi anlatan "Od Gelini” adlı dramı 1927'de kaleme alınmıştır. Vatanseverlik, kadın hakları ve din eserin önemli temalarını oluşturur.

Cabbarlı, "Aydın", “Oktay Eloğlu", ve "Od Gelini" eserlerinde halkın bozuk yanlarını şiddetle tenkit eder, devrin ütopik bir hayali haline gelmiş bulunan "sosyalist düzen"in kurulmasına yardımcı olmaya çalışır.

Cabbarlı, sanatını çok ustalıklı olarak kullanmayı, her zaman ve her cemiyette geçerli olabilecek içtimaî, siyasî ve daha çok beşerî problemleri işlemeyi becermiş, kahramanlarını güdümlü edebiyatın esiri olmaktan kurtarmayı başarabilmiştir. Cabbarlı Sovyetlerin güdümlü edebiyat propagandasını yaparken kendi sanat anlayışını da göstermeyi başarmıştır. Komünist Partisi bu yüzden olacak kendisine hep şüpheyle bakmış, kontrolü sağlamaya çalışmıştır. Stalin zamanında tutuklanarak hapse atılmış, bir süre sonra hapisten çıkarılmıştır. Uzun zamandır kalp rahatsızlığı olan Cabbarlı, 31 Aralık 1934'te kalp krizinden vefat etmiştir.

1920'de yaşanan Rus Devrimi'yle rejimin değişmesi, sosyal, kültürel, edebî hayatta önemli islahatları da beraberinde getirmiştir. Yeni rejimin baskıcı ve şiddetli tarafı, halk nazarında çok geçmeden hissedilmeye başlar. Bu durum edebî çevrede de görülür. Artık gerek tiyatro, matbuat, gerekse nesir yazarları, 1920'den önceki gibi serbest yazamamışlardır. Rejimin ideolojik görüşüne uygun yazmayan yazarlar ya sürgüne gön- 
derilmiş ya da ölümle cezalandırılmıştır. Bu durumla ilgili Yavuz Akpınar dönemin manzarası hakkında şu bilgiyi verir,

"1920'den önceki devirde olgun eserler yazmış sanatçllar değişik yollar tercih ettiler. Bir kısmı sustu, bir kısmı etliye sütlüye karışmamayı; küçük bir vazife alıp kenara çekilmeyi tercih etti. Bir kısım yazarlar da yeni devre ayak uydurmaya çalışarak istenilen tarzda eserler yazmayı denediler. 1920'den önce eserler vermiş, sosyalist veya sosyal demokrat görüşlü kimseler ise pek fazla zorlamadan yeni devrin değerlerine uygun eserler kaleme aldılar. Her şeye rağmen kendi bildiği yolda gitmeye inandığ çalışanlar da yok değildi. Bu gibi şahsiyetler arasında Hüseyin Cavid örnek gösterilebilir. A. Hakverdili, Cafer Cabbarl, Celil Mehmetkuluzade, Abdulla Şaik gibileri ise kendi şahsiyetlerini korumaya çalışarak hem yeni devre hem de kendi zevk ve görüşlerine uygun havada eserler yaratmaya çalıştı. Bir kısmı başarabildi, bir kısmı da Stalin'in terör deorinde hayatın kaybetti." (Akpınar, 1994, s.75)

\section{Sonuç}

Azerbaycan tiyatrosunun geçmişi çok eskilere dayanır. Azerbaycan maişetini, gelenek göreneklerini kısacası Azerbaycan değerlerini yansıtan ilk oyunlar, Azerbaycan geleneksel halk tiyatroları olarak bilinir. Bu oyunlar ritüellerin, inançların, merasimlerin, mevsim zamanlarının, tabiat şartlarının, yer ve zamanın özelliklerine göre çeşitlenir. Azerbaycan geleneksel halk oyunların bazıları bugün de Azerbaycan'da sergilenmekte olup geçmişle gelecek arasında köprü görevi görmektedir. Azerbaycan modern tiyatrosunun doğuşuna kadar bu oyunlar, tiyatrodaki boşluğu doldurmuş, Azerbaycan tarihi-kültürel bağı toplum arasında canlı tutmuştur. Azerbaycan'da modern tiyatro 19. yüzyılın ortalarından itibaren başlar. Bu dönem Müslüman Türk dünyasının ilk tiyatro yazarı Mirza Fetali Ahundov tarih sahnesine çıkmış, yazdığı tiyatrolarıyla halkı gaflet uykusundan uyandırmaya çalışmıştır. Ahundov; tiyatroyu, toplumu cehaletten uzaklaştırmak, cemiyeti terbiye etmek, kötü alışkanlıklardan kurtulmak kısaca içtimaî bozukluklardan arınmak için en tesirli sanat olarak görür. Realist ve eleştirel olarak kaleme aldığı tiyatro eserleri halkın ufkunu açmıştır. Ahundov'un açtığı yolda ilerleyen Necef Bey Vezirov da tiyatro eserleriyle Azerbaycan millî tiyatrosunun kurulmasında 
büyük önem arz eder. Vezirov'la Azerbaycan modern tiyatrosu yükselişe geçmiş, dünya çapında önem kazanan mühim eserler ortaya çıkmıştır. 1920 Rus İhtilaline kadarki eserler -bazıları Çar döneminde çeşitli sansüre maruz kalmışsa da- Azerbaycan içtimaî ve siyasî hayatını yansıtmıştır. $\mathrm{Bu}$ eserler Azerbaycan hayatını aksettiren birer ayna vazifesi görür. 1920'den sonra siyasî idarenin değişmesi Azerbaycan tiyatrosunu da etkilemiş, Sosyalist Azerbaycan Edebiyatı'nın güdümlü sanat dalı haline gelmiştir. 
EXTENDED ABSTRACT

\section{Azerbaycan Tiyatrosu Üzerine Bir İnceleme (Geçmişten Sovyet Dönemine Kadar) \\ *

\author{
Ümit Akın \\ Bandırma On Yedi Eylül University
}

Today, it is assumed that the theatre, which is of great importance in the culture of all societies, came into being with the festivities held in the name of Dionysus, the God of wine in the ancient Greek civilization. Theatre then becomes independent from religion and becomes art. Mehmet Fuat indicates in his History of Theatre book that theatre is the oldest branch of art by saying it is older than religion.

The lifestyles of nations, natural events, and religious ceremonies constitute the main subject of the theatre. Although the emergence of theatre in Azerbaijan is not fully known, its origin dates back a long time before. Many elements such as the lifestyles of Azerbaijani Turks, traditions, religious ceremonies, weddings, natural events constitute the sources of the theater. These meetings play an important role in the formation of the Azerbaijani public theatre. At the same time, these plays serve as a bridge between the past and the future.

Researchers do not point to a specific date but state that the beginning of Azerbaijani theatre goes back very far. Before the transition to the modern theatre in Azerbaijan, there were several plays played among the people. These were called square theater because they were played in squares or public theatres.

Azerbaijani folk dances played an important role in the formation of modern theatre. In Azerbaijani life, these theatres have provided a rich range of plays in the sense of traditional theatre, which has always attracted interest. The most popular folk dances are Mezheke, Kosa Kosa, Kilim Arasi, Shah Salim, Karavelli, Shebeh, Sayaci, Laglagi, Dervish, Kevser, Cutcu Shumu, Yug, Tenbeki Kendirbaz, Yel Baba-Dede, GoduGodu, Gudul. These plays contributed to the development of Azerbaijani traditional theatre as well as the enrichment of characters and types. Moreover, the contribution of folk plays and actors to the formation of 
Azerbaijani professional theatre increased the value of folk theatres. Players such as Sidki Ruhulla, Abbas Mirza Sharifzade, Huseyin Araplinski played in the public theatre before the written theatre, and later became the first actors to appear on the stage of the Azerbaijani theatre.

Vahap Yurtsever states in his Azerbaijan Drama Literature work that, modern theatre in Azerbaijan appeared in the second half of the XIXth century and that the annexation of North Azerbaijan to Russia as a result of the Russian-Iranian war was effective in the appearing (Yurtsever, 1950, 6). We can base this situation on the fact that Azerbaijan is politically, economically and culturally dependent on Russia after the occupation.

Just as the first theatrical activities in the Ottoman Empire took place in the places where non-Muslims lived heavily, the first theatrical activities in Azerbaijan also took place under the influence of the Russians. Laying the foundation of the first theatre building in Tbilisi (1849) and opening it in 1851 by Knyaz Vorontsov, the general governor of the period, confirms this. Vorontsov has also been involved in encouraging Turkish, Georgian and Armenian intellectuals of nations that depended on Russia in the Caucasus to write theatrical works (Akpinar, 1994, 58). As a result of these incentives, Mirza Fethali Ahundov (1812-1878), the first theatre writer in the modern sense of the Muslim world, appeared and wrote the work of Hekayet-i Molla İbrahimhalil Kimyager [The Chemist Hekayet-i Molla Ibrahimhalil The Chemist] in 1850. Ahundov also wrote the works in the year he wrote his work; Hekayet-i Mösyö Jordan Hekimi- Nebatat ve Dervish Mesteli Shah Cadukini-Meshur (Mösyö Jordan) [Hekayet-I Monsieur Jordan Physician - Nebatat and Dervish Mesteli Shah CadukiniMeshur (Monsieur Jordan)] and [Lenkeran Hanmmn Veziri] Vizier of the Lankaran Khan. Ahundov, the innovative modern intellectual of Azerbaijan, wrote Hekayet-i Hirsi Guldurbasan in 1852, Haji Gara in 1853, and Murafa Vekilleri in 1855. These works, however, were not published until 1859 due to Russian censorship in his native language, Azerbaijani Turkish.

Towards the end of the 1880s, a certain Theatre Collective ( Habib Bey Mahmutbeyov, Sultan Mecit Ganizade, Najafgulu Veliyev) was formed. Theatre lovers who meet in this collective thought the theatre as the most important field of activity for the progress of the nation. From time to 
time, they have worked tirelessly for the development of Azerbaijan's theater, even though they have been attacked by bigots and ignorant people, and they have tried to move forward the nation they belong to. Hasan Bey Zardabi, Najaf Bey Vezirov, Sultan Mecit Ganizade and Neriman Narimanov, who made great contributions to the development of Azerbaijani theatre in these years, performed several works as actors, directors, and writers of plays. The construction of a special theatre building in Baku in 1883 by the oil-rich Hajji Zeynel Abidin of Azerbaijan provided a suitable environment for the development of the modern theatre of Azerbaijan.

The first theatre plays are usually played on feast days, and a short introductory speech is sung at the entrance of the theatre about its importance and the play to be shown. Ahundov's comedies were included in the theatre repertory earlier. Then works of other theatre writers such as N.B Vezirov and Vasaq Medetov were played. Writers such as Neriman Narimanov, Hashim Bey Vezirov, Resit Bey Efendiyev and Jalil Mehmetkuluzade, who started their creativity in the 1890s, went down the path of Ahundov and portrayed Azerbaijani life in a realist way, not only showing the problems but also trying to give suggestions for solutions.

The change of regime with the Russian Revolution in 1920 brought with it important reforms in social, cultural and literary life. The oppressive and violent side of the new regime soon began to be felt in the eyes of the people. This is also seen in the literary environment. Now both theatre, press and prose writers could not write as freely before 1920 . Writers who did not write in accordance with the ideological view of the regime were either exiled or sentenced to death.

As a result, we can say that with Vezirov, the modern theatre of Azerbaijan has risen, and important works that have gained importance worldwide have emerged. The works up to the 1920 Russian Revolution -some of which were subjected to various censorship during the Tsar period - reflected Azerbaijani social and political life. These works serve as a mirror to the Azerbaijani life. The change of political administration after 1920 also affected the Azerbaijani theatre and became the guided art branch of socialist Azerbaijani literature. 


\section{Kaynakça / References}

Ahmedov, C. M. (1987). M. F. Ahundov talim terbiye hakkında. İlmi Eserlerin Tematik Mecmuası. Bakı: Azerbaycan Devlet Üniversitesi, s.564.

Ahundov, S. S. (2005). Seçilmiş Eserleri. Haz., Nadir Velihanov, Bakı: ŞarkGarb.

Ahundzâde, M. F. (2005). Eserleri üç cildde, C I, Hzl. Nadir Memmedov, Bakı: Şark-Garb.

Akhmedov, H. (2016). Abdurrahim Bey Hakverdiyev'in hayatı, sanatı ve eserleri. Yayımlanmamış Y. Lisans Tezi, İzmir: Ege Üniversitesi Türk Dünyası Enstitüsü, s. 72.

Akın, Ü. (2018). Azerbaycan'ın ilk trajedisi Musibet-i Fahreddin üzerine bir inceleme. Akademia Sosyal Bilimler Dergisi, 1, 61-73.

Akın, Ü. (2018). Azerbaycan tiyatrosu ve romanında öncü bir kadın: Sakine Hanım Ahundzade, Filoloji Alanında Yenilikçi Yaklaşımlar. Ankara: Gece Akademi.

Akpınar, Y. (1988). Mirza Fethali Ahundov, komediler (Temsilat). İzmir: Ege Üniversitesi Basımevi.

Akpınar, Y. (1993). Azerbaycan Edebiyatı. Türkiye Dışındaki Türk Edebiyatları Ansiklopedisi., Ankara: Kültür Bakanlığı Yayınları, 4, 311.

Akpınar, Y. (1994). Azerî Edebiyatı Araştırmaları. İstanbul: Dergâh Yayınları.

And, M. (1973). Elli yılın türk tiyatrosu. İstanbul: Türkiye İş Bankası Kültür Yayınları, s.58.

And, M.(2010). Başlangıcından 1983'e Türk tiyatro tarihi. İstanbul: İletişim Yayınları, s.21.

Arif, M. (1954). Cafer Cabbarlı. Bakı: Gızıl Şark Matbaası.

Cabbarlı, C. (1959). Azerbaycan dram teatrı. Bakı: Azerbaycan Dövlet Neşriyatı.

Cabbarlı, C. (2005). Eserleri II-III. C, Hzl. AZE, Bakı: Şarq-Garp.

Cavid, H. (2005). Eserleri. I.C, Haz. Turan Câvid, Bakı: Lider Neşriyat, s.7.

Çelebi D.B. (2007). Türkiye ve Azerbaycan'daki çocuk oyunları ve oyuncaklarının karşılaştırmalı incelemesi. Yayımlanmamış Y. Lisans Tezi, Muğla Üniversitesi, s. 111.

Çetişli, İ. (2016). Metin tahlillerine giriş 2 (Hikaye-Roman-Tiyatro). Ankara: Akçă̆ Yayınları, s. 72.

Ahmedov, A. Mir. (1960). Azerbaycan edebiyatı tarihi. Bakı: Azerbaycan SSR İlimler Akademiyası Neşriyyatı,2, s.564.

Fuat, M.(2003). Tiyatro tarihi. İstanbul: MSM Yayınları. 
Güney, A. (2011). Aristoteles Ve Bertolt Brecht'in İngiliz tiyatrosuna etkileri. e-Journal of New Word Sciences Academy, 6 (1). 135-144.

Hakverdiyev, A. B. (2005). Seçilmiş eserleri. C 1, Hzl. AZE, Bakı: Lider Neşriyat.

Hzl. Çelik, Y. (2002). Sanat ve edebiyatta temel kavramlar. İstanbul: Nehir Yayınları.

Kasımzade, F. (1954). N.B. Vezirov eserleri. II.C. Bakı: Azerbaycan Devlet Neşriyat1, s.182.

Kasımzade, F. (1960). "XIX. Asrın ikinci yarısında edebiyat" XIX. Asır Azerbaycan Edebiyat Tarihi (Азербайсан Едебийаты Тарихи С.2. Бак1: Азербайсан ССР Елимлер Академийасы Нещриййаты) II.C. Bakı: Azerbaycan Sovyet Elmler Akademiyası Neşriyatı, s.153.

Kengerli, A. A. (2008) Azerbaycan'da romantik Türkçülük. Aktaran Metin Özarslan, İstanbul: Doğu Kütüphanesi, s.321.

Keskin, F. (2011). Üzeyir Hacıbeyli'nin "Er Ve Arvad" “O Olmasin Bu Olsun” Ve "Arşın Mal Alan" isimli piyeslerinin incelenmesi. Yayımlanmamış Y. Lisans Tezi, Ankara: Gazi Üniversitesi Sosyal Bilimler Enstitüsü.

Məmmədov, K. (1995). Necef Bey Vezirov. Bakı: Azerbaycan Devlet Neşriyatı.

Memmedova, M. (2017). Azerbaycan Ve Anadolu folklorunda mevsimi oyun ve temaşalar. Motif Akademi Halkbilimi Dergisi. 10 (19), 137-148.

Merdanov, M. (2011). Azerbaycan'ın tahsil tarihi, C.1, Bakı: Tahsil Neşriyatı, s.295.

Orucov, T. (2006). Karavelli ve Latifelerin Janr Hususiyyetleri. Azerbaycan Şifahi Halk Edebiyyatına Dair Tedkikler XIX. Bakı: Sada Neşriyatı, s. 142-143.

Rəhimli, İ. (2003). Üç asrın otuz ili. (Akademik milli dram teatrı bugün). Bakı: Gapp- Poligraf.

Rəhimli, İ. (2005). Azerbaycan taatr tarixi. Bakı: Çaşığlu.

Sarı, İ. (2016). Türk'ün savaşları: Türklerin islam dünyasındaki liderliği ve savaşları. İstanbul: Net Medya Yayıncılık.

Sultanlı, A. (1964). Azerbaycan dramaturgiyasının inkişaf tarihinden. Bakı: Azerneşr, s.248.

Tahirkızı, U. (2014). Çiçəksiz baharın fidanı. Halk Cephesi, S.13. Bakı: http://www.anl.az/down/meqale/xalqcebhesi/2014/oktyabr/395369.h $\underline{\text { tml }}$ 18.9.2019 tarihinde erişim sağlandı.

Tekiner, S. (1987). Azerbaycan şairi Hüseyin Cavid, Milli Türkoloji Kongresi. Ankara: Azerbaycan Türk Kültürü Dergisi Yayınları 36, s.111. 
Türkiye dışındaki Türk edebiyatları antolojisi. (1993). Üzeyir Hacıbeyli Maddesi. C.IV, Ankara: Kültür Bakanlığı Yayınları, s.311.

Uygur, E. (2005). Toplumların yeniden yapılanmasında edebiyat adamlarının rolü ve sovyet döneminde Azerbaycan örneği. III. Kültür ve Kimlik Araştırmaları Sempozyumu, İstanbul: Koç Üniversitesi Kültür Araştırmaları Derneği.

Uzunburun Derviş. (1890). Bakü'de avukatlı. Kaspi, 14 Fevral. No: 33, s.13.

Vezirov, N.B. (1911). Vay Şeleküm Meelleküm. Neşr: Hacı Samed Haydarov, Bakı: Seda Matbaası, 12 Fevral.

Yurtsever, V. (1950). Azerbaycan dram edebiyatı. Ankara: Azerbaycan Kültür Derneği Yayınları Bayur Matbaası, s.6.

\section{Kaynakça Bilgisi / Citation Information}

Akın, Ü. (2021). Azerbaycan tiyatrosu üzerine bir inceleme: Geçmişten sovyet dönemine kadar. OPUS-Uluslararası Toplum Araştırmaları Dergisi, 17(38), 5586-5630. DOI: 10.26466/opus.748125 